\title{
LUCIANO E O CINISMO: O CASO ALCIDAMAS
}

\author{
Olimar Flores-Júnior* \\ Universidade Federal de Minas Gerais
}

\begin{abstract}
One of the axes of the so called "Lucianic Question" is the relationship of the writer from Samosata with the philosophy, and especially with the Cynicism. Even though the idea of a "Cynic Lucian" or a "Philosopher Lucian" has been abandoned, modern criticism still seems to hesitate before the image of the Cynicism that we find in the pages of this author, which fluctuate in a more or less explicit way between the approval and praise in one hand, and the attack and sarcasm in the other. This article seeks to re-examine this issue in the light of an analysis of the figure of the Cynic Alcidamas, a character that appears in the Symposium or The Lapiths. The hypothesis to be defended here is that the seemingly pitiless construction of this Cynic, the most "buffoon" of the guests in the described banquet, actually reveals the sympathy and admiration that Lucian feels about the tradition of which Diogenes of Sinope was the chief representative.
\end{abstract}

KEYWORDS: Lucian of Samosata; Alcidamas; Cynicism; sympathy; admiration.

Domingo nóis fumos

num samba no Bexiga,

na rua Major, na casa do Nicola.

A mezzanotte o'clock

saiu uma baita de uma briga,

era só pizza que avoava,

junto com as bracciola.

Nóis era estranho no lugar

e não quisemos se meter:

não fumos lá pra brigar,

nóis fumos lá pra comer.

^ ofloresj@yahoo.com.br 
Na hora "h" se enfiemo debaixo da mesa, fiquemo ali de beleza, vendo o Nicola brigar. Dali há pouco, escuitemo a patrulha chegar e o sargento Oliveira falar: "não tem importância, vou chamar duas ambulância!"

[falado:] "Calma, pessoal, a situação aqui tá muito cínica!

Os mais pior vai pras Clínica!”

(Adoniran Barbosa, Um samba no Bexiga) ${ }^{\star \star}$

(1)

omo como ponto de partida destas breves reflexões uma citação de um autor morto no final do último século, e que em princípio pouco ou nada tem a ver com Luciano ou com a chamada "tradição luciânica":

Cultivar o equívoco, desconcertar com convicções tão claras quanto as suas é uma proeza. Era inevitável que se acabasse por perguntar sobre a seriedade de seu fanatismo, que se acentuassem as restrições que ele próprio manifestou à brutalidade de suas palavras e que se assinalassem com insistência suas raras cumplicidades com o bom senso. Quanto a nós, não lhe faremos a injúria de tomá-lo por um indiferente. O que nos interessará nele será sua soberba, sua maravilhosa impertinência, sua falta de equidade, de medida e, às vezes, de decência. Se não nos irritasse o tempo todo, ainda teríamos a paciência de lê-lo? As verdades que defendeu valem unicamente pela deformação apaixonada que lhes infligiu o seu temperamento (...). Alguns de seus exegetas, não sem pesar, questionaram a sua sinceridade, quando a rigor deveriam alegrar-se com o mal-estar que lhes inspirava: sem suas contradições, sem os mal-entendidos que criou - por instinto ou por cálculo - a seu próprio respeito, seu caso há muito tempo estaria liquidado, sua carreira encerrada, e ele conheceria o azar de ser compreendido, a pior coisa que pode acontecer com um autor.

\footnotetext{
$\star \star \mathrm{O}$ acadêmico sisudo que defende com zelo os domínios estritos do trabalho científico julgará inoportuna e de mau gosto a epígrafe; ou, valendo-se da condescendência que os espíritos superiores frequentemente manifestam diante do que é "menor", achará nela a expressão mais ou menos inócua de um humor vulgar. O leitor de boa vontade será mais sensível e saberá talvez apreciar a coincidência evocada. A um e outro eu lembraria que a mistura de gêneros, do "alto" com o "baixo", do "erudito" com o "popular", do sério com o cômico é precisamente aquilo que os gregos definiram numa única palavra: spoudogéloios, uma das marcas que caracterizam o kynikòs trópos, a que o próprio Luciano não foi indiferente.

${ }^{1}$ Uma versão preliminar deste artigo foi apresentada durante o V Colóquio Interdisciplinar do Grupo de Pesquisas Sobre as Sociedades Antigas (GIPSA), "Luciano e a tradição luciânica", realizado em Ouro Preto entre os dias 13 e 17 de abril de 2009.
} 
No esforço de uma aproximação sem dúvida um pouco inusitada, poder-se-ia afirmar que o mesmo olhar desencantado sobre o homem e suas empresas é o traço que liga o autor dessas linhas, o ensaísta romeno, Emil Cioran, ${ }^{2}$ e o versátil escritor "pós-antigo"3 que foi Luciano; mas uma diferença de temperamento parece separar os dois autores: enquanto o requisitório de Cioran contra as ilusões que governam a existência humana reveste um pessimismo melancólico e aparentemente sombrio, em Luciano, as mesmas ilusões se convertem em objeto de troça e riso, cujos efeitos parenéticos o escritor de Samósata soube explorar como poucos.

Por outro lado, no que concerne ao personagem a que se refere a passagem citada, a saber o contra-revolucionário Joseph de Maistre, apenas o acidental de sua genealogia poderia ligá-lo à tradição luciância: Joseph de Maistre é o irmão mais velho de Xavier de Maistre, cuja Viagem ao redor do meu quarto, publicada em 1795 (continuada pela Expedição noturna em torno do meu quarto, de 1829) participaria, segundo alguns por intermédio de Sterne, da herança de Luciano. ${ }^{4}$ Esse de Maistre mais novo seria inclusive um dos vetores pelos quais o "vírus da ironia" fora transmitido a Machado de Assis, um vírus "inventado por algum grego da decadência", 5 em que sem dúvida se deve reconhecer, não a figura de Sócrates, mas a sombra incômoda de Menipo de Gadara. O próprio Machado, na voz de seu personagem Brás Cubas, teria reivindicado para sua "obra difusa", escrita "com a pena da galhofa e a tinta da melancolia", "a forma de um Sterne ou de um Xavier de Maistre, tendolhe acrescentado ainda "algumas rabugens de pessimismo". ${ }^{6}$ Assim, esse

${ }^{2}$ Cf. Cioran, op. cit., p. 2 para a citação. Este ensaio foi publicado originalmente como o prefácio de uma coletânea de textos de Joseph de Maistre (Joseph de Maistre. Textes choisis et présentés par E. M. Cioran. Monaco: Éditions du Rocher, 1957); é republicado posteriormente como obra avulsa (Cioran, E. M. Essai sur la pensée réactionaire: à propos de Joseph de Maistre. Paris: Fata Morgana, 1977), e integra mais tarde a coletânea Exercices d'admiration: essais et portraits (Paris: Gallimard, 1986).

${ }^{3}$ A expressão é de J. L. Brandão, logo na abertura de seu $A$ poética do Hipocentauro: literatura, sociedade e discurso ficcional em Luciano de Samósata (op. cit., 2001).

${ }^{4}$ Cf. sobre o assunto Rouanet, op. cit.

${ }^{5}$ Cf. Machado de Assis, op. cit., 1961b, p. 114. Sobre o assunto, cf. Brandão, op. cit., 2001/2002, p. 125-144.

${ }^{6}$ Cf. Machado de Assis,op. cit., 1961a, p. 9. Na primeira edição de Memórias póstumas de Brás Cubas, o nome de Charles Lamb figurava entre os nomes de Sterne e Xavier de Maistre, mas desaparece nas edições posteriores: cf. Rouanet, op. cit., p. 31-32, 
"conúbio" proposto por Machado de Assis inscreve sua literatura numa longa linhagem que, passando por Varrão, Sêneca, Petrônio, Apuleio e o próprio Luciano - apenas para citar alguns nomes antigos -, remonta ao referido Menipo (ou a Mônimo de Siracusa ${ }^{7}$ ), filósofo cínico, discípulo de Crates de Tebas, ${ }^{8}$ cuja obra (de Menipo) - hoje perdida se caracterizava pela mistura de gêneros e por uma inovadora combinação de seriedade e riso, incluindo títulos como Venda de Diógenes

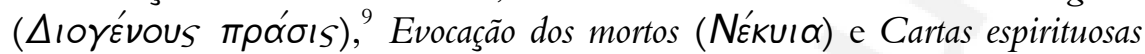

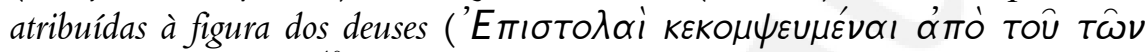

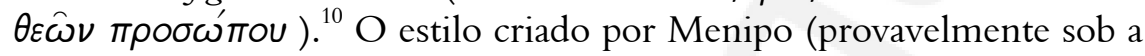
influência de Mônimo) valeu-lhe, junto a Estrabão, o adjetivo spoudogéloios, "sério-cômico", ${ }^{11}$ enquanto Marco Aurélio o inclui entre "esses seres presunçosos, que debocham da vida infeliz e efêmera dos homens". ${ }^{12}$ Por outro lado, segundo o juízo de Diógenes Laércio, suas obras "nada ofereciam de sério e estariam repletas de zombaria". ${ }^{13}$

Mas voltemos à citação de Cioran. Proponho o artifício, algo lúdico, impreciso e metodologicamente discutível, de tirá-la de seu contexto e esquecer momentaneamente a quem ela se refere, para introduzi-la no âmbito do tema geral da tradição luciânica, e no de seu aspecto particular que deve me ocupar, isto é, Luciano e o cinismo.

que afirma ainda (p. 25) que a metáfora do ateniense que achava que todos os navios que aportavam no Pireu eram seus teria sido "pilhada" por Machado em Viagem em torno do meu quarto, embora ela apareça também em outros autores, incluindo La Rochefoucauld e o próprio Luciano (cf. Rego, op. cit., p. 93-96).

${ }^{7}$ Mônimo de Siracusa, também cínico, foi aluno de Diógenes de Sínope e de Crates de Tebas (cf. D.L. VI 82). Diógenes Laércio afirma que "ele escreveu obras ligeiras misturadas com uma seriedade sutil" (D.L. VI 83), sendo, por isso, considerado o criador do spoudogéloion, uma característica que Menipo teria incorporado em suas próprias obras e que passou a ser um dos traços típicos daquilo que mais tarde ficou conhecido como "sátira menipeia", da qual Luciano seria um dos herdeiros. Sobre o assunto, cf. Helm, op. cit., 1906.

${ }^{8}$ D.L. VI, 95. Sobre o problema do discipulado de Menipo junto a Crates (e não junto a Metrocles), cf. considerações de Goulet-Cazé, 1986a, p. 247-252.

${ }^{9}$ D.L. VI, 29.

${ }^{10}$ D.L. VI, 101.

${ }^{11}$ Estrabão XVI, 2, 29.

${ }^{12}$ Marco Aurélio, Meditações VI, 47.

${ }^{13}$ D.L. VI, 99. Sobre os desdobramentos antigos da tradição inaugurada por Menipo, cf. estudo de Relihan, op. cit. 
Aceitando essa proposição, devemos ficar indiferentes aos detalhes do texto, que se refere por exemplo a um autor, ao seu fanatismo e às suas conviç̧ões claras, embora desconcertantes, na medida em que convivem com contradições e com o cultivo dos mal-entendidos. Hesitaríamos sem dúvida a quem aplicar a descrição: a Luciano ou ao cinismo, na figura de algum dos seus representantes? Apegando-nos a uma certa ambiguidade não dissimulada - essa ambiguidade seria mesmo intencional - que o texto surpreende na personagem descrita, e conscientes de que o mínimo que se pode dizer sobre Luciano é que se trata de um "clássico controvertido", ${ }^{14}$ talvez tendêssemos para ele. Não faltariam autores, antigos e modernos, para nos confortar em tal posição. Já Fócio, no século IX, observava ao mesmo tempo a falta de seriedade, de posição clara e a excelência do estilo de Luciano:

Ele parece ser um daqueles para quem nada é inteiramente digno de respeito, pois, ridicularizando e debochando das opiniões dos outros, não expõe ele mesmo aquelas em que acredita, a menos que se diga que sua opinião é a de não ter nenhuma opinião. Em matéria de estilo, ele é excelente (...). ${ }^{15}$

Também segundo a conclusão um pouco frustrada de John Dryden, que no século XVII escrevera uma Vida de Luciano, ele seria "por demais vacilante, por demais irresoluto para ser uma coisa mais do que outra, e ele levou os outros a suspeitarem que não sendo mais isto do que aquilo, ele não devia ser absolutamente nada". ${ }^{16}$ Enfim, retrocedendo outra vez no tempo, a informação mirabolante da Suda e leva o tom da crítica, mas segue na mesma direção: Luciano teria sido morto estraçalhado por cães em razão de suas blasfêmias, e teria herdado o fogo eterno na companhia de Satanás. ${ }^{17}$

Por outro lado, poderíamos igualmente admitir que o cinismo seria o verdadeiro objeto dessas linhas. Nesse caso, a acusação se voltaria contra a falta de seriedade e decência, contra a brutalidade, a impertinência e a enorme capacidade de irritar dos filósofos cínicos. Também aqui não nos

\footnotetext{
${ }^{14}$ Cf. Brandão, op. cit., 2001, p. 12. A mesma afirmação é feita por Branham, op. cit., p. 12: I know of no classical author who has received such contradictory evaluations.

${ }^{15}$ Fócio, Biblioteca, cod. 128. Salvo indicação contrária, todas as traduções neste estudo são de minha responsabilidade e, sem qualquer pretensão literária, não terão outro objetivo que o da inteligibilidade mínima dos textos comentados.

${ }^{16}$ Dryden, J. Life of Lucian, apud Branham, op. cit., p. 215.

${ }^{17}$ Suda, s.v. Loukianos.
} 
faltaria a autoridade de antigos e modernos para justificar a escolha. Num libelo intitulado Sobre os estoicos, cujo objetivo era atacar o estoicismo explorando precisamente o seu parentesco com o cinismo, o filósofo epicurista Filodemo de Gadara (séc. I a. C.), por exemplo, imbuído de um espírito sectário e alimentando a polêmica entre as escolas filosóficas do seu tempo, promove uma verdadeira "cruzada" contra as doutrinas de Diógenes e Zenão, entre as quais, da sua perspectiva, não havia grandes diferenças. Filodemo, como ele mesmo pretende, fundamenta suas acusações com a própria literatura cínico-estoica que teria sido preservada em "catálogos e bibliotecas" ainda acessíveis em seu tempo. ${ }^{18}$ Do Sobre os estoicos de Filodemo, conservado em dois papiros de Herculano (PHerc. 155 e339) muito mutilados, puderam ser restituídas, entre outras, as seguintes passagens, em que o desdém irônico se transforma rápido em ataque franco:

Transcrevamos agora as belas obras desses homens [scil. Diógenes e Zenão], afim de perdermos o menor tempo possível com as suas ideias. Agrada a esses santos: adotar a vida dos cães; utilizar as palavras em sua crueza, sem atenuá-las, e utilizá-las todas; masturbarem-se em público (...); que as crianças sejam comuns a todos; ter relações com as próprias irmãs, mães e outras pessoas da família, seus irmãos e filhos, e não se absterem de nenhuma parte [do corpo] com vistas à cópula (...); que aqueles que morrem sejam, na maioria dos casos, comidos durante um banquete comum (...). [Segundo eles] convém ainda que os homens matem seus pais e que nenhuma das cidades e leis que conhecemos sejam objeto de consideração (...). ${ }^{19}$

Por seu turno, lembrando justamente o uso livre que os cínicos fazem das palavras, que Filodemo menciona logo no começo de sua invectiva, Cícero anota:

Não convém dar ouvidos aos cínicos nem a alguns estoicos que foram quase cínicos; eles criticam e debocham, com a desculpa de que nós dizemos serem infames nas palavras coisas que não são torpes, e que, aquelas que são, nós a chamamos por seus nomes. ${ }^{20}$

E mais adiante, na mesma obra, resume a sentença: "A doutrina cínica deve ser inteiramente rejeitada, pois ela é de fato contrária ao pudor moral, sem o qual nada de correto ou belo pode existir". ${ }^{21}$

\footnotetext{
${ }^{18}$ Filodemo, De stoicis col. XV Dorandi.

${ }^{19}$ Filodemo, De stoicis col. XVIII Dorandi.

${ }^{20}$ Cícero, De officiis I, 35, 128.

${ }^{21}$ Cícero, De officiis I, 41, 148.
} 
Recuperando um outro aspecto presente na crítica de Filodemo, Teófilo de Antioqueia, apologista cristão que viveu no século II d. C., atribui ao cinismo (aqui representado por Diógenes e associado, como em Filodemo, ao estoicismo) a prática da antropofagia, o que bem valeria uma aproximação com a acusação de blasfêmia que a Suda impinge a Luciano: tanto num caso como no outro, uma imaginação hipertrofiada infunde na violência do ataque um tom quase cômico. Na passagem trata-se de uma composição epistolar - o texto de Teófilo interpela seu destinatário nos seguintes termos:

Já que tens lido muita coisa, como te parecem as doutrinas de Zenão, Diógenes e Cleanto, expostas em seus livros, que ensinam a antropofagia, dizendo que os pais deverão ser cozidos e devorados pelos filhos e que, se alguém não quiser ou se recusar a tomar parte nessa abominável refeição, será ele mesmo devorado? Em meio dessas doutrinas, eleva-se uma voz ainda mais ímpia, a de Diógenes, que ensina que os filhos conduzam os próprios pais ao sacrifício e os devorem. ${ }^{22}$

Entre os modernos, encontramos olhares mais lúcidos, mas igualmente severos e contundentes em seu julgamento sobre o cinismo. Hegel, em suas Lições sobre a história da filosofia, liquida o "problema" dos cínicos em umas poucas páginas, deplorando o fato de que eles não tenham acrescentado grande coisa à filosofia e afirmando que, de um modo geral, "eles não foram mais do que repugnantes mendigos, a quem produzia indizível satisfação irritar as pessoas com suas ações despudoradas". ${ }^{23}$

Mais recentemente, o historiador da Antiguidade, Moses Finley, em sua única incursão pelo cinismo antigo, publicada pela primeira vez em 1960, reconhece que "Diógenes foi longe demais", ${ }^{24}$ que ele "levou a autodisciplina socrática ao absurdo, a crítica socrática ao niilismo, e o naturalismo à vulgaridade e à indecência". ${ }^{25}$ E arremata:

\footnotetext{
${ }^{22}$ Teófilo, Ad Autolycum III 5 (SVF III 750; SSR V B 134). É improvável que Teófilo tenha se inspirado no De stoicis de Filodemo, obra que, ao que tudo indica, ele sequer chegou a ler: cf. Teófilo, Ad Autolycum III 6 (SVF III 750). Sobre o assunto cf. considerações de Goulet-Cazé, op. cit., 2003, p. 69-72.

${ }^{23}$ Cf. a seção sobre os cínicos no segundo capítulo do volume II das Vorlesungen über die Geschichte der Philosophie de G. W. F. Hegel.

${ }^{24}$ Cf. Finley, op. cit., p. 109.

${ }^{25}$ Cf. Finley, op. cit., p. 109.
} 
(...) a crítica de Diógenes era puramente destrutiva. Ele somente atacava - a política, os hábitos e costumes sociais, as práticas religiosas. Como seu herói Héracles, limpava as cavalariças de Áugias, mas não via necessidade de colocar algo novo no lugar do lixo (...). Diógenes era, em suma, um filósofo de pouca filosofia, um pregador da virtude que endossava aquilo que era tido como vício pela maioria dos homens, um escarnecedor, um destruidor, um Sócrates enlouquecido. ${ }^{26}$

O que tentei até aqui, partindo de uma citação "sequestrada" de seu contexto e de sua temática - procedimento pouco ortodoxo que não terá outro valor que o do pretexto e o da sugestão - foi estabelecer uma "comparação cruzada" entre os juízos que puderam ser formulados sobre Luciano, de um lado, e sobre os cínicos, de outro. Constata-se que, em muitos casos, o que se diz de um poderia também ser aplicado ao outro. Como consequência dessa constatação, eu afirmaria o seguinte a respeito do problema da relação entre Luciano e o cinismo: que há entre eles uma certa simpatia, termo que tomo em sua acepção etimológica, mais no sentido de uma "simpatia entre" do que uma "simpatia por" (o uso desse termo no vocabulário musical também é sugestivo: duas notas iguais, ainda que de alturas diferentes, podem vibrar por simpatia). De certo modo, Luciano representaria, no âmbito da história da literatura e da crítica social e de costumes, o mesmo que os cínicos representam no âmbito da história da filosofia. Arriscaria ainda a levar essa afirmação um pouco mais longe, sugerindo a hipótese de que essa simpatia está na base da admiração que, como penso, Luciano experimenta diante do cinismo. E que a chave para o entendimento da relação entre Luciano e o cinismo reside na natureza dessa admiração. ${ }^{27}$

$\mathrm{Na}$ verdade, esse é o aspecto do problema que explica o recurso ao texto de Cioran que evoquei no princípio, e que retomo agora rapidamente, restituindo-o em sua dimensão própria para, no entanto, destacar nele um único elemento. Nesse ensaio sobre Joseph de Maistre - incluído num volume que leva o sintomático título de Exercícios de admiração -, Cioran demonstra como a admiração, enquanto categoria do sentimento e faculdade do espírito, pode se manifestar de maneira complexa, aparentemente ambígua: há nas páginas de Cioran um efetivo elogio a Joseph de Maistre; mas nada seria mais estranho ao agnosticismo

\footnotetext{
${ }^{26}$ Cf. Finley, op. cit., p. 109.

${ }^{27}$ Há que se considerar aqui os sentidos "laterais" implicados nessa admiração, que se manifesta também como espanto, surpresa.
} 
melancólico de Cioran do que, por exemplo, o fanatismo católico de de Maistre, para quem "não pode haver no universo nada mais calmo, mais circunspecto, mais humano por natureza do que o tribunal da Inquisição". ${ }^{28}$ Todavia, Cioran confessa sua admiração diante dos livros de de Maistre que, "impregnados de uma raiva tonificante, nunca aborrecem" ${ }^{29}$ e diante do fato de que "elevando o menor problema ao nível do paradoxo e à dignidade do escândalo, manejando o anátema com uma crueldade combinada com fervor, ele criou uma obra rica em excessos, um sistema que não cessa de nos seduzir e nos exasperar". ${ }^{30}$ O texto de Cioran não apenas ilustra a complexidade de uma admiração, que implica em si o exercício de um juízo muitas vezes conflitante, mas deixa entrever ainda que ela será tanto mais complexa quanto mais complexos e ricos forem seu sujeito e seu objeto.

Afirmar que Luciano nutre uma certa admiração pelo cinismo não é nenhuma novidade no campo dos estudos luciânicos, embora essa posição apareça mitigada em função de seus muitos ataques contra os sucessores de Diógenes e Crates (tal como em Os fugitivos). No campo dos estudos sobre o cinismo, nem sempre se tem dado a devida importância a Luciano como fonte legítima para o conhecimento dessa corrente filosófica. Nesse último caso a obra de Luciano teria sobretudo um "valor literário" Luciano professaria na verdade um "cinismo literário" -, , o que exclui tacitamente o seu interesse para a história da filosofia propriamente dita; ${ }^{32}$ ou então, segundo uma perspectiva igualmente redutora, Luciano nos apresentaria um "cinismo idealizado", relativizando assim sua importância para uma reconstrução histórica do cinismo antigo. ${ }^{33}$

\footnotetext{
${ }^{28}$ Cf. Cioran, op. cit., p. 3.

${ }^{29}$ Cf. Cioran, op. cit., p. 3.

${ }^{30}$ Cf. Cioran, op. cit., p. 1.

${ }^{31}$ Cf. Schwartz, op. cit., p. 148.

${ }^{32}$ Cf. Goulet-Cazé, op. cit., 1990, p. 2763-2768.
}

${ }^{33}$ Por comodidade, assumo como desnecessário retomar aqui toda a fortuna crítica em torno da relação de Luciano com o cinismo, que seria na verdade um dos ramos - o mais espinhoso talvez - do problema da relação de Luciano com a filosofia em geral e com as escolas filosóficas em particular, problema que estaria no cerne mesmo da chamada "questão luciânica”. Para um rápido e útil percurso por algumas opiniões sobre este tema, remeto para Nesselrath, op. cit., p. 121-135 (menos convincente seria a tentativa desse autor de "reabilitar" o cinismo em Luciano). Para uma revisão detalhada da bibliografia sobre a suposta "filiação filosófica" de Luciano, cf. Fuentes González, op. cit., 2005, p. 131-160 (cf. notadamente p. 153-155). 
Em todo caso, encontramos na Antiguidade um testemunho que, mais do que marcar o apreço de Luciano pelo cinismo, faz dele um cínico de pleno direito. Trata-se de Isidoro de Pelúsio, que em uma de suas cartas inclui Luciano entre os cínicos que teriam ridicularizado Platão. ${ }^{34}$ Entre os modernos, a ideia de um "Luciano cínico" ou mesmo de um "Luciano filósofo", ${ }^{35}$ afora talvez uma única exceção, ${ }^{36}$ parece ter sido definitivamente abandonada, mas sua preferência pelo modelo cínico - o que não implica em adesão - é defendida com bons argumentos. Um dos principais argumentos nesse sentido seria a constatação de que Luciano elege vozes cínicas para exprimir o que constituiria o seu próprio ponto de vista: são os Diógenes, Crates e Menipos que aparecem, por exemplo, no Diálogo dos mortos. Luciano buscaria assim no cinismo de uma época já pretérita os meios de expressão de sua crítica social. A eleição dessas vozes se explicaria pelo fato de que Luciano percebe no cinismo antigo, em primeiro lugar, a adequação entre a vida do filósofo e a doutrina que ele prega e, depois, um conjunto de virtudes cardinais - a liberdade, a independência e a parrésia $-{ }^{37}$

${ }^{34}$ Cf. Isidoro de Pelúsio, Carta IV 54 (SSR I H 14). Para o problema específico do "cinismo idealizado", cf. Billerbeck, op. cit., p. 319-338.

${ }^{35}$ Cf. Helm, op. cit., p. 189, que afirma logo no começo de seu estudo: Daß Lucian niemals Philosoph war, ist heute bekannt.

${ }^{36}$ Cf. Joly, op. cit., 1981, p. 417-426. Também J.-P. Dumont (Lucien, op. cit., 1993, p. 8) escreve: L'auteur, Lucien de Samosate, capitale du royaume de Comagène en Syrie septentrionale (125-192), fut un rhéteur et philosophe grec. Mais prudente, Fuentes González, op. cit., 2005, p. 131, apresenta-o como littérateur et penseur.

${ }^{37}$ A mais "cínica" dessas três virtudes é sem dúvida a parrésia. Ela constitui o elemento essencial a partir do qual se estabelece a simpatia entre Luciano e o cinismo, de que falávamos há pouco. Embora Luciano não seja ele mesmo um parresiasta, da mesma maneira como o foram Diógenes e os outros cínicos, o conjunto de sua obra denuncia e põe a nu as incoerências da tradição e da cultura grega, assumindo portanto - neste caso, sim, no plano da literatura - a função própria da parrésia, que o cinismo exerce politicamente. Registre-se a propósito que em seu último curso no Collège de France, proferido entre fevereiro e março de 1984 (portanto três meses antes de sua morte), Michel Foucault tratou precisamente do fenômeno da parrésia, entendida como uma forma de veridicção e como um dos componentes verificáveis do que ele chamou de "processos de subjetivação", se impondo a partir da Antiguidade tanto como possibilidade e limite da democracia, quanto como instrumento necessário às práticas da "direção de consciência". Reconhecendo na parrésia um dos mais importantes traços do cinismo - importância já atestada com o próprio Diógenes: D.L. VI, 69 -, Foucault dedica à tradição cínica, que ele submete a uma análise extremamente acurada e estimulante, toda uma sequência de aulas. Este curso foi publicado com o oportuno 
que ele reivindica para a própria obra. ${ }^{38} \mathrm{O}$ problema é que esse tipo de argumento conduz justamente à concepção de um "cinismo idealizado" em Luciano: ele recusaria o cinismo de seu tempo para apegar-se quase que exclusivamente ao cinismo antigo, mas recolhendo dele apenas o que lhe interessa, apenas o que serve a seus propósitos. Dessa maneira, nos Diálogos dos mortos, por exemplo, Diógenes é um interlocutor arguto capaz de perturbar a ordem das coisas e demolir impiedosamente as ilusões que os valores estabelecidos alimentam, mas está muito longe do filósofo despudorado de que falam outras fontes antigas, que se masturbava em praça pública, que recomendava a comunidade de mulheres e crianças (de uma forma muito mais radical, convém precisar, do que aquela que encontramos exposta da República platônica), e que admitia sem complexo o incesto e a antropofagia. A estratégia de Luciano corresponderia de fato a um recurso retórico.

Para resolver o problema e tentar recobrar o realismo de Luciano, então ameaçado, evocou-se a figura de Demônax que encarnaria, segundo alguns, o seu modelo ideal de filósofo. ${ }^{40}$ Mas a lembrança de Demônax nesse debate não diminui as dificuldades mais do que levanta outras: antes de mais nada, a própria identidade desse filósofo não é segura, já que ele é conhecido quase que exclusivamente pela biografia que lhe consagra Luciano; haveria portanto razões para suspeitar que se tratasse de uma ficção, criada com vistas justamente a dar corpo e voz a uma doutrina filosófica ideal, uma hipótese afinal pouco convincente. ${ }^{41}$ Por outro lado, a própria adesão de Demônax a uma escola definida não pode ser afirmada sem ressalvas, já que ele mesmo declarara (segundo Luciano) quando lhe perguntaram que filósofo ele preferia: "Todos são admiráveis, mas eu venero Sócrates, admiro Diógenes e amo Aristipo". 42 Se na formação de um cínico podiam estar combinadas as

título de Le courage de la vérité: le gouvernement de soi et des autres II (Paris: Gallimard/Seuil, 2009). Para alguns elementos de reflexão em torno dessa obra, permito-me remeter o leitor para Flores-Júnior, op. cit., 2009/2010, p. 93-109.

${ }^{38}$ Cf. Brandão, op. cit., 2001, p. 51-64.

${ }^{39}$ Cf. Bompaire, op. cit., p. 182-185.

${ }^{40}$ Cf. Brandão, op. cit., 2001, p. 51-64.

${ }^{41}$ Ver sobre o assunto o detalhado artigo de Fuentes González, op. cit., 2009, p. 139158, que demonstra com bons argumentos a historicidade do filósofo Demônax sem, contudo, negar que o seu retrato tenha sido, em alguns aspectos, "retocado" por Luciano na composição de sua biografia.

${ }^{42}$ Luciano, Vida de Demônax 62. Eu mesmo recentemente traduzi e anotei essa obra: cf. Luciano de Samósata. Biografias literárias. Trad. Jacyntho Lins Brandão et alii. Belo Horizonte: UFMG, 2014 (no prelo). 
influências de Sócrates e Diógenes, a intromissão de Aristipo nessa série surpreende, pelo menos segundo a tradição mais difundida. Talvez fosse o caso de ver em Demônax a prática de um cinismo edulcorado, mais leve ou "domesticado", que equivaleria na verdade a um certo "ecletismo" filosófico. ${ }^{43}$

Mas o principal obstáculo à construção da imagem de um "Luciano amigo dos cínicos", ${ }^{44}$ cara, por exemplo, a Rudof Helm, que explicava essa predileção a partir da matriz menipeana de muitos escritos de Luciano, é sem dúvida o fato de que encontramos disseminada ao longo de sua obra todo um inventário de ataques dirigidos contra o cinismo. Também nesse caso, uma solução engenhosa foi proposta: as invectivas de que os cínicos são vítimas ao longo da obra de Luciano apenas representariam o reverso de seu apreço, confirmando-o. ${ }^{45}$ Nessa linha de raciocínio, observa-se que Luciano investe sistematicamente contra os falsos filósofos, aqueles que ele mesmo denomina skhémata philosóphon, simulacros de filósofos, isto é, os que são filósofos apenas na aparência, ${ }^{46} \mathrm{e}$ que se ele é particularmente severo na crítica dos cínicos é porque, tendo eleito o cinismo como o modelo ideal de filosofia, a deturpação desse modelo seria sentida por ele como algo de mais grave do que a deturpação da doutrina de outras escolas. Concilia-se assim a predileção de Luciano pelo modelo cínico, refletida no uso "positivo" de certos cínicos históricos, com o que ele nos apresenta, por exemplo, em Os fugitivos, numa passagem que foi considerada o mais impiedoso texto jamais escrito sobre o cinismo no período imperial. ${ }^{47}$ Sob a pluma de Luciano, é a própria Filosofia, convertida em personagem, que se queixa:

Eis que a cidade se encontra repleta desse tipo de fraude, sobretudo dessa gente que se inscreve sob o nome de Diógenes, Antístenes e Crates e que se coloca sob a égide do cão. No entanto, essas pessoas jamais imitaram o que a natureza dos cães tem de útil, como a vigilância, a aptidão para guardar a propriedade, o amor ao dono e a boa memória. Ao contrário, os ganidos, a gulodice, a avidez, a lascívia

\footnotetext{
${ }^{43}$ A prática filosófica do ecletismo parece ter sido introduzida por Potamon de Alexandria: cf. D.L. I, 21. Sobre o assunto, cf. Hadot, op. cit., p. 147-162, e Dillon; Long, op. cit.

${ }^{44}$ Eu deixo de lado aqui a defesa do cinismo que encontramos no pequeno diálogo $O$ Cínico, atribuído a Luciano, mas que a crítica moderna tende a considerar como espúrio. Cf. sobre o problema Bieler, op. cit. e Flores-Júnior, op. cit., 1998/1999, p. 122-133.

${ }^{45}$ Cf. Brandão, op. cit., 2001, p. 51-64.

${ }^{46}$ Luciano, Banquete 30.

${ }^{47}$ Cf. Goulet-Cazé, op. cit., 1990, p. 2767.
} 
permanente, a adulação e o hábito de rodar em torno dos que lhes dão qualquer coisa e de permanecer perto das mesas, tudo isso elas copiaram cuidadosamente. ${ }^{48}$

O inconveniente desse argumento é que ele nos faz recair no problema da idealização do cinismo, já que nos obriga a aceitar que aquilo que desagrada a Luciano não faz parte do cinismo "autêntico", que o que contraria a sua expectativa seria na verdade a deturpação de um modelo. Ora, em muitos casos, o que Luciano deplora como corrupção da filosofia de Diógenes nos é descrito por outras fontes como sendo praticado pelo próprio Diógenes.

Diante desses impasses, o que proponho é reconhecer na crítica e nos ataques que Luciano dirigiu contra os cínicos de seu tempo o exercício de uma admiração, segundo os termos que defini acima. Ousaria afirmar ainda que nas camadas mais profundas dessa admiração, Luciano tem consciência de que entre ele e os cínicos há de fato uma forma de simpatia. E é precisamente na figura de Alcidamas, personagem do Banquete ou Os Lápitas, que pretendo "testar" minha hipótese. Trata-se de um cínico sem dúvida ficcional $^{49}$ diante do qual mesmos os intérpretes mais empenhados em defender o apreço de Luciano pelo cinismo desanimam. H.-G. Nesselrath, por exemplo, que se alinha declaradamente com a posição de Helm, para quem Luciano seria na verdade favorável aos cínicos, observa:

A figura de um cínico que é em quase todos os aspectos negativa (como se deve admitir) aparece no Banquete, onde o personagem, que leva o nome de Alcidamas, é objeto de uma sátira verdadeiramente desenfreada; mas, uma vez mais, convém constatar que todos os outros filósofos que aparecem nesse diálogo são também eles coisa bem diferente de figuras edificantes. Nas circunstâncias ridículas e absurdas do banquete nupcial descrito aqui por Luciano, Alcidamas é provavelmente o mais bufão, mas não necessariamente o mais maléfico ou o mais sinistro de todos esses patifes filosóficos. ${ }^{50}$

Não creio que o melhor que se possa dizer sobre Alcidamas é que, no contexto em que aparece, ele apenas não é pior do que os outros filósofos, o que equivaleria a considerar que ele se dissolve, sem maiores distinções, em meio ao desfile de filósofos charlatães e hipócritas. Mas é o próprio Nesselrath que constata a diferença de Alcidamas, sem,

\footnotetext{
${ }^{48}$ Luciano, Os fugitivos 16.

${ }^{49}$ Cf. Goulet-Cazé, op. cit., 1986, p. 246.

${ }^{50}$ Cf. Nesselrath, op. cit., p. 133 (itálico meu).
} 
contudo, tirar todas as consequências desta constatação: Alcidamas é o mais bufão. Caberia então explorar todas as dimensões do papel desempenhado pelo cínico e, examinando cada uma de suas intervenções, tentar demonstrar que de fato ele brilha no banquete de que participa com uma luz diferente da dos outros convivas, uma luz que desvela, como acredito, o favor com que Luciano o descreve.

Mas neste ponto uma advertência se impõe: não devemos esperar, nem mesmo de forma velada, que Luciano “absolva” Alcidamas. É antes na forma de sua condenação que penso se poder encontrar a preferência de Luciano por ele. Por outro lado, se Luciano tende a construir a imagem do representante de cada escola segundo a composição de "tipos" - ou, propriamente, de estereótipos - baseados num certo senso comum ou numa visão "popular" dos filósofos profissionais (procedimento, em parte, semelhante ao adotado no Leilão de filósofos), não se pode excluir que ele tenha manipulado a construção desses tipos conforme suas próprias convicções. Restaria então demonstrar por que, no contexto do banquete descrito, aquele que foi considerado o mais bufão dos convivas e o "melhor" dos filósofos aí representados coincidem no modelo cínico incarnado por Alcidamas.

Devemos admitir enfim que, no Banquete como em outras obras, o objetivo de Luciano não é atacar a prática da filosofia em si, mas denunciar o mau comportamento de muitos daqueles que dela se ocupavam, e que gozavam de grande reputação e estima. Em escritos como o Hermótimo, o alvo visado é o sectarismo e a adesão irrefletida a uma determinada escola em detrimento do juízo crítico e do (bom) senso comum, ${ }^{51}$ enquanto no

${ }^{51}$ A fala final do Hermótimo, em que Hermótimo, convencido pelos argumentos de Licino, decide abandonar de vez o seu curso de filosofia junto a um mestre estoico, não deve nos induzir em erro: De hoje em diante, se alguma vez, e contra a minha vontade, ao caminhar na rua, topar com um filósofo, desviar-me-ei, evitá-lo-ei como a um cão danado (Luciano, Hermótimo 86, trad. de C. Magueijo. In: Luciano. Hermotimo ou As escolas filosóficas. Prefácio, tradução e notas de Custódio Magueijo. Lisboa: Inquérito, 1986). São os filósofos profissionais e o sectarismo que realmente constituem o alvo de Luciano. O que se pretende é expor a vacuidade dos skhémata philosóphon (dos Halbphilosophen ou dos filosofastri, tal como a expressão é traduzida, respectivamente, por autores alemães e italianos, como bem lembra Brandão, op. cit., 2001, p. 286, n. 24). É, aliás, precisamente sobre o problema da aparência, ou seja, de um exterior a que não corresponde nenhum estofo, fosse bom senso ou inteligência, que se concentra a "apostasia" de Hermótimo: Vou daqui, pois então, com este propósito: modificar até mesmo o meu aspecto exterior. Sim, dentro em breve, já não verás uma barba farfalhuda e espessa, como agora, nem um modo de vida austero, mas sim um estilo completamente descontraído e livre (86). Essa conclusão desencantada de Hermótimo vem na sequência imediata de um 
Banquete, são as próprias escolas filosóficas "institucionais" que são, uma a uma, descreditadas; também aí o que se busca mostrar é que em matéria de virtude o leigo pode ser superior ao filósofo profissional. Para Luciano, a tarefa maior de qualquer filosofia parece ser, em princípio, a de tornar o filósofo mais virtuoso. ${ }^{52}$ Fora desse princípio, ela se torna uma empulhação que se deve evitar - é o caso do Hermótimo ${ }^{53}$ ou um espetáculo ridículo,

esclarecimento de Licino que redefine o alcance de sua crítica: E não cuides, caro amigo, que foi por preconceito relativamente ao Pórtico, ou arrebatado por um ódio especial contra os estoicos, que eu disse tudo quanto disse; ao contrário, as minhas palavras estendem-se a todos. Efetivamente, dir-te-ia precisamente a mesma coisa se tu tivesses optado pela doutrina de Platão ou de Aristóteles e condenasses as outras indistintamente è revelia. No caso presente, porém, e uma vez que deste a tua preferência à filosofia estoica, as minhas palavras deram a impressão de estarem dirigidas contra o Pórtico, quando nada têm de especial contra ele (85). Se no plano ficcional do diálogo a justificativa vale para Licino, que é personagem, ela não vale de modo necessário para Luciano, que é autor. A escolha de um estoico - e não do representante de uma outra escola qualquer - na composição da obra parece confirmar a hipótese de Caster, op. cit., segundo a qual, na escala de "preferências" filosóficas de Luciano, o estoicismo ocuparia o último lugar, e validaria ainda, conforme lembra Fuentes González, op. cit., 2005, p. 153, o juízo de Joly, op. cit., 1980, p. 53, para quem o estoicismo era a bête noire privilegiée de Luciano. Nesse contexto, Fuentes González, op. cit., 2005, p. 153, lembra também que a exceção feita a Epiteto não deve surpreender, já que se trata de um estoico "cinicizante", cujo pensamento se volta prioritariamente para uma pedagogia moral. Seja como for, o trecho final do Hermótimo (que pode, aliás, ser interpretado em chave irônica), parece cobrar uma maior cautela na identificação, muitas vezes apressadamente admitida no plano das obras, entre Luciano e Licino, uma identificação que, aliás,constitui a base de um dos argumentos mobilizados pela crítica moderna para recusar a paternidade luciânica a $O$ cínico; para uma breve discussão sobre esse problema, cf. FloresJúnior, op. cit., 1998/1999, p. 122-133.

${ }^{52}$ Vai precisamente nesse sentido a reflexão de Licino, o narrador do Banquete: "Enquanto essas coisas tão variadas aconteciam, eu refletia comigo mesmo sobre aquilo que naquela hora me vinha ao espírito, que de nada serve ter conhecimento

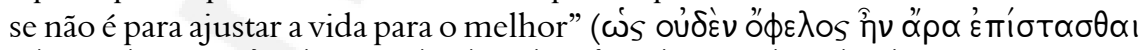

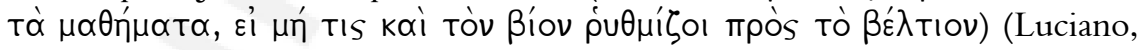
Banquete 34).

${ }^{53}$ Há, entretanto, no Hermótimo, nuances que não poderão ser tratadas aqui com o detalhamento devido. Por exemplo: no já evocado desfecho do diálogo (cf. nota 51), os argumentos de Licino, que conduzem à decisão de Hermótimo de, dali pra diante, jamais ter qualquer relação com filósofos (uma decisão aparentemente tão radical tomada, aliás, no breve espaço de tempo de uma conversa - quanto foi fervorosa a sua adesão ao estoicismo durante seus longos anos de estudo), não se resumem a insistir sobre os limites da filosofia como instrumento para a edificação moral. Eles deixam 
como no caso do Banquete. É aliás o que constata Licino, o interlocutor principal deste último diálogo, diante dos eventos que presenciara e que agora narra a um amigo:

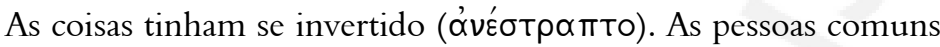

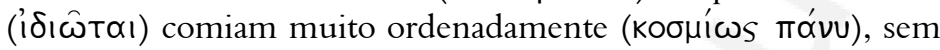
demonstrar embriaguez ou excesso. Apenas riam e reprovavam

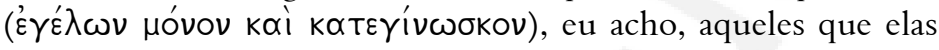
admiravam, julgando pelas aparências serem pessoas importantes. Os sábios, ao contrário, eram impudentes e abusados, se empanturravam de comida, gritavam e se estapeavam. ${ }^{54}$

também entrever - coisa que, de toda evidência, Hermótimo não compreende - que esses limites não anulam per se o valor da filosofia: nesse sentido, pode-se dizer que Licino considera (a contrapelo de toda a tradição socrática), sem contudo subscrevêla explicitamente, a possibilidade da disjunção entre conhecimento e virtude. A anedota, contada pelo próprio Licino (80-83), sobre um velho professor de filosofia que fora acusado de ter sido incapaz de tornar seu aluno um homem melhor, tem uma conclusão que faz despontar, em meio ao sarcasmo com que a história é narrada, um problema "sério". Na resposta que dá à acusação de que é vítima - "resposta de velho" (ó

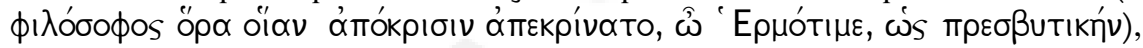
precisa Luciano (uma precisao cujo sentido exato caberia investigar)-, o velho professor (um anônimo que Dumont, in: Lucien, op. cit., 1993, p. 204, caracteriza como o "estoico

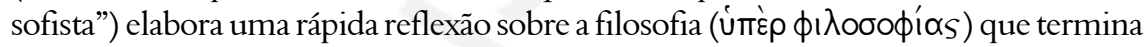
com uma pergunta indignada: "Se, porém, ele costuma bater na mae ou raptar donzelas,

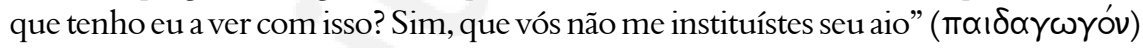
(82). Nesse contexto, seria necessario colocar em perspectiva o conselho de Licino a Hermótimo, que soa como a "moral da história" de todo o diálogo: "Portanto, também tu (já que tal é a tua opinião) farias bem melhor em decidir viver, daqui para o futuro, uma vida como a de toda a gente: serás um cidadão como os demais, não porás esperanças em coisas bizarras e estúpidas, nem (se fores sensato) te envergonharás pelo fato de, já velho, mudares de opinião e te passares para coisa melhor" (84). Outra vez, deve prevalecer a prudência: seria temerário fazer do conselho de Licino, inteiramente determinado pela situação particular do diálogo e pela psicologia de seu interlocutor, a expressão do ponto de vista de Luciano, que se dizia (se é certo, como sugere Brandão, op. cit., 2001, p. 53, considerar o que lemos no Sobre a dança como uma espécie de confissão do próprio Luciano, colocada, mais uma vez, na boca de Licino) "moderadamente familiarizado com a filosofia" (

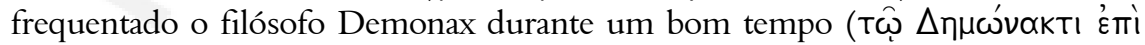

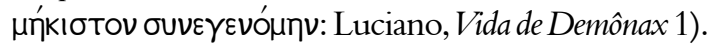

${ }^{54}$ Luciano, Banquete 35. 
O entrecho desse diálogo, com certeza fictício, consiste resumidamente no relato, feito por Licino ao amigo Fílon, dos fatos ocorridos na casa de um certo Aristêneto, durante o banquete em comemoração das núpcias da filha deste último, Cleântis, com o jovem Quéreas que parecia ter, segundo concordam os dois interlocutores, duas virtudes maiores: uma, a de ser bem comportado e ter inclinação para a

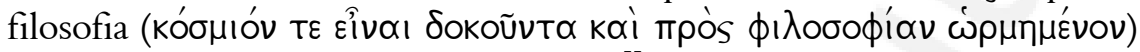
- e, outra, a de ser filho de um banqueiro. ${ }^{55}$ Naquela ocasião se reuniram em torno da mesma mesa, em meio às pessoas comuns, homens de ciência e de letras em geral, mas sobretudo filósofos, escolhidos entre os mais importantes representantes de cada escola. ${ }^{56}$ Ademais, além do noivo que, sendo um dos discípulos de Íon, debutava na filosofia pelo caminho do platonismo, ${ }^{57} \mathrm{o}$ irmão da noiva, Zenão, contava-se entre os alunos do estoico Difilo ${ }^{58}$ e o pai de ambos, o próprio Aristêneto, anfitrião da festa, não era, como Licino tem o cuidado de precisar, "um desses ricos como muitos que existem por aí, mas cuida da educação e tem convivido a maior parte da vida com sábios". 59 Ao contrário do que se poderia esperar em uma reunião dessas, a pretensa virtude dos intelectuais em título produz uma cena cômica tendo como verdadeiros protagonistas o vício e a hipocrisia. Trata-se, enfim, de uma inversão que Luciano constrói e explora com grande habilidade. ${ }^{60}$

Sem alongar a análise do texto, caberia ressaltar, para o que interessa diretamente ao que proponho aqui, as intervenções do cínico Alcidamas, em particular os seus momentos extremos: a sua chegada e o final do banquete que se dissolve numa pancadaria generalizada. Esses dois momentos seriam já suficientes para demonstrar que a figura de Alcidamas, exposta e condenada em todo o seu excesso, constrói-se no

\footnotetext{
${ }^{55}$ Luciano, Banquete 5.

${ }^{56}$ Luciano, Banquete 10.

${ }^{57}$ Luciano, Banquete 7.

${ }^{58}$ Luciano, Banquete 6.

${ }^{59}$ Luciano, Banquete 10.

${ }^{60}$ Já se observou, com relação aos procedimentos narrativos adotados nesta como em outras obras, a dívida de Luciano com a estrutura de composição de alguns diálogos platônicos; nesse sentido, o Banquete de Luciano representaria uma "inversão paródica" da obra homônima de Platão, conforme sugere Branham, op. cit. (sobretudo, p. 104-123). Consulte-se ainda, sobre a tradição literária que tematiza o banquete de sábios na Antiguidade, o estudo de Romeri, op. cit., que oferece uma análise bastante detalhada do Banquete de Luciano (p. 191-246).
} 
fim das contas sobre a base de uma admiração que lhe confere um estatuto bastante diferente do das outras personagens evocadas no diálogo. ${ }^{61}$

Lembremos, antes de mais nada, que Alcidamas irrompe na festa

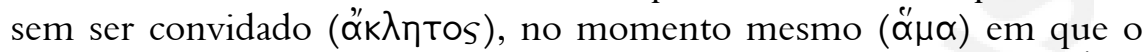
peripatético Cleodemo, cochichando no ouvindo do platônico Íon, chamava a atenção para a falta de modos do velho Zenótemis, representante ilustre do Pórtico que no início do banquete já tinha o manto lambuzado de molho e, não contente de se atirar avidamente sobre todos os pratos, sem pensar nos que se serviriam depois dele, ainda repassava ao seu servo outras tantas porções para serem levadas para casa, convencido de que a manobra não era notada por ninguém

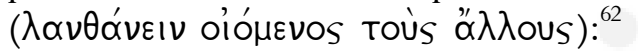

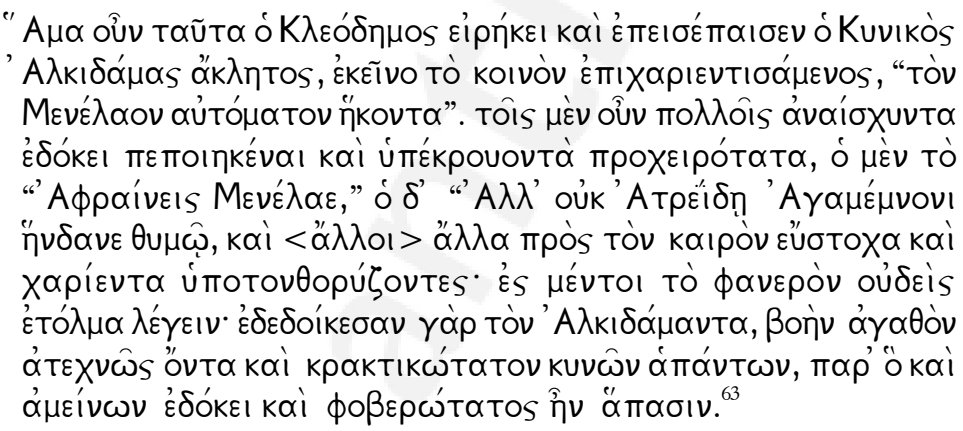

No momento mesmo em que Cleodemo tinha falado essas coisas, irrompeu o cínico Alcidamas, sem ser convidado, citando por brincadeira aquele verso conhecido: "Chega Menelau por vontade própria". ${ }^{64}$ Para a maioria dos convivas ele parecia ter feito coisa muito indecente, e davam em resposta os versos mais à mão: um, o "insensato Menelau", 65 outro o "mas não agradava no ânimo ao atrida Agamêmnon", 66 enquanto

\footnotetext{
${ }^{61}$ Deixo provisoriamente de lado neste estudo, por uma questão de espaço, dois "pontos altos" do Banquete protagonizados por Alcidamas: a briga com o bufão Satírion (cf. parágrafos 18-19) e o estupro da flautista (cf. parágrafo 46). Por mais surpreendente que possa parecer, não acredito que essas passagens forneçam um argumento contrário à tese que sustento aqui, de que Alcidamas reflete e confirma a simpatia que, de certa forma, une Luciano e os cínicos. Voltarei a estas duas passagens numa outra ocasião.

${ }^{62}$ Luciano, Banquete 11.

${ }^{63}$ Luciano, Banquete 12.

${ }^{64}$ Homero, Ilíada II, 408.

${ }^{65}$ Homero, Ilíada VII, 109.

${ }^{66}$ Homero, Ilíada I, 24.
} 
outros, murmurando, soltavam gracejos adequados à situação. Mas o fato é que ninguém ousava falar abertamente, pois temiam Alcidamas, que é realmente bom de grito ${ }^{67}$ e o mais barulhento de todos os cães, pelo que também parecia o melhor e era o mais temido de todos.

Difícil considerar como traço de virtude o hábito de entrar em festas sem ser convidado, mas devemos ver as coisas mais de perto. Em primeiro lugar, há na passagem uma oposição clara entre dois tipos de comportamento: de um lado, a aparição ostensivamente provocadora de Alcidamas, o "mais barulhento [ou o mais latidor] de todos os cães" e, de outro, a atitude sorrateira e velada de alguns convidados - mal velada, diga-se de passagem e, portanto, cômica, no caso de Zenótemis -, ditada sem dúvida pela covardia ou pela vergonha. Assim, a vergonha que pode sentir Zenótemis, e que decorre apenas do interesse em preservar a imagem de seriedade e sisudez de que depende sua reputação, não o leva a recusar o vício, mas a praticá-lo justamente por pensar que ninguém notava. De seu lado, Cleodemo, ao surpreender os excessos do velho estoico, sem querer se indispor com os outros presentes nem se expor na situação, se contenta em sussurrar o fato ao pé do ouvido de Íon, escolhendo, entre a simples indiferença e a denúncia da falta, o termo médio de uma condenação acanhada, que corresponde de algum modo a uma certa tolerância; na verdade, mais do que condenar o gesto, Cleodemo, um peripatético, divide com um platônico o prazer da cena de um estoico pego em flagrante delito. A personagem de Cleodemo ganha maior nitidez se lembrarmos que um pouco adiante ele será um dos protagonistas de (mais) um episódio constrangedor envolvendo os filósofos que Licino conta a Fílon, "pois convém" - justifica-se Licino com ironia - "falar de todas as coisas que correram ao paralelo (" $\sigma \alpha$

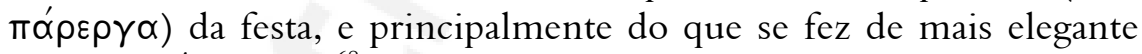
( $\gamma \lambda \propto \phi \cup \rho \omega ́ \tau \varepsilon \rho \circ \nu) ":{ }^{68}$ Cleodemo flertava furtivamente com o jovem servo encarregado de lhe servir o vinho e, descobertos acidentalmente,

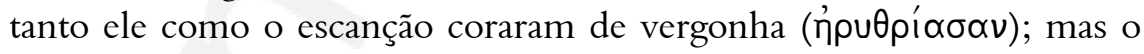
filósofo, sem coragem de admitir suas intenções, fazia de conta (тробтоооuн́vou) que nada tinha feito. ${ }^{69}$

Nesse cenário de desfaçatez, fingimento e ações sub-reptícias, a aparição de Alcidamas, na forma de uma atitude soberana e afirmativa,

\footnotetext{
${ }^{67}$ Homero, Ilíada II, 408.

${ }^{68}$ Luciano, Banquete 15.

${ }^{69}$ Luciano, Banquete 15.
} 
representa uma ruptura. Alcidamas de fato irrompe - o verbo є̇пєı (na passagem, no aoristo, exprimindo justamente o ponto de partida de uma situação nova) indica uma intervenção abrupta, não raro desagradável e violenta, que altera o estado das coisas $-{ }^{70}$ sem convite, não em uma reunião qualquer, mas em um "banquete de homens sábios,

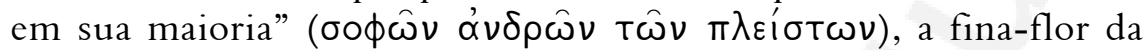
intelectualidade, um verdadeiro "Museu. ${ }^{71}$ É necessário frisar que o comportamento desses "homens sábios" desenvolve-se ao longo do diálogo num crescendo contínuo, tornando cada vez mais evidentes os seus vícios, que redunda na inversão final mencionada acima. Já a atitude de Alcidamas permanece essencialmente a mesma durante todo o banquete, e a sua entrada é de imediato considerada escandalosa por aqueles mesmos "sábios", que julgavam que o cínico estivesse fazendo

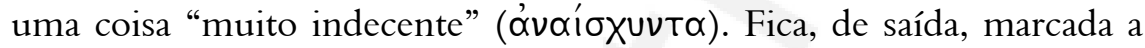

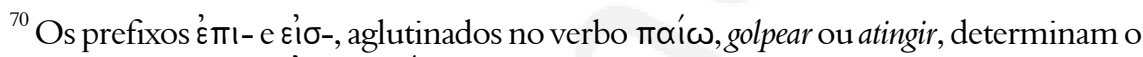

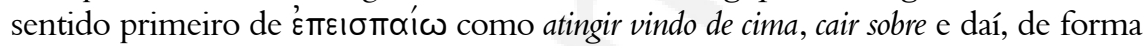
análoga, o de irromper; trata-se enfim de uma ação que causa surpresa, ou propriamente um susto, um sobressalto desagradável. Note-se que Luciano emprega esse mesmo

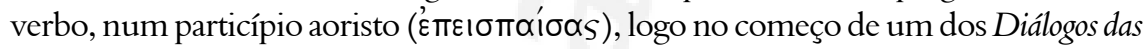
meretrizes, para descrever uma situação que nos ajuda a perceber os efeitos que a chegada de Alcidamas provoca no Banquete. É a jovem Pártenis que explica à amiga Cóclis a razão de seu choro: "Foi aquele soldado grandalhão, o amante da Crócale, que me bateu, quando me pegou tocando flauta na casa dela, contratada pelo rival dele, o Gorgo.

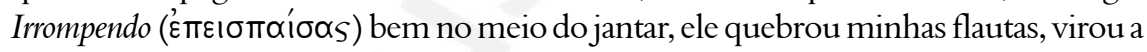
mesa e derrubou os copos. Esse tal soldado - acho que se chama Deinômaco -, junto com um companheiro, ainda arrastou aquele caipira (áypôkov) do Gorgo da sala do banquete pelos cabelos, e eu nem sei se ele sobreviverá, Cóclis, pois era muito o sangue que escorria do seu nariz, e o seu rosto ficou todo inchado e roxo" (Luciano, Diálogos das meretrizes 15,1). E, mais adiante, a mesma Pártenis dá outros detalhes do episódio (repare-

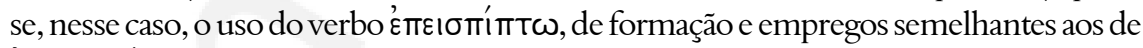

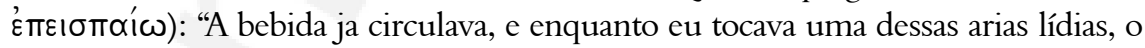
fazendeiro se levantou para dançar, Crócale batia palmas, e tudo estava muito agradável. Foi aí que se ouviram uma confusão e uma gritaria, e alguém batendo no portão de fora.

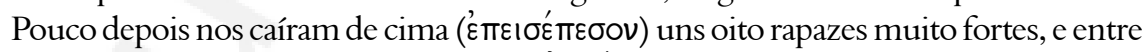
eles o Megarense. Num instante ('̇uӨús), tudo ficou de pernas para o ar

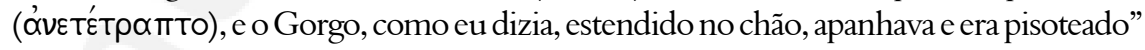
(Luciano, Diálogos das meretrizes 15,2).

${ }^{71}$ Bompaire, in: Lucien, op. cit., 1998, p. 205, n. 12, observa que o termo Museu

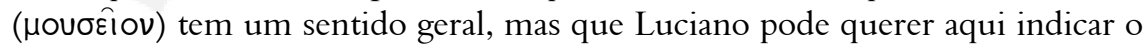
celebre estabelecimento de Alexandria, herdeiro, de certa forma, das escolas filosoficas de Atenas. 
diferença do cínico frente a seus pares: se Alcidamas apenas parecia o melhor ( $\alpha \mu \varepsilon i ́ v \omega \nu ~ \varepsilon ́ \delta o ́ k \varepsilon ı)$, ele de fato era o mais temível de todos

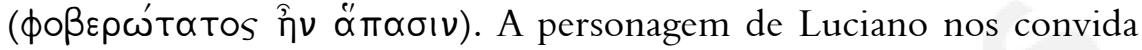
então a refletir sobre o que pode significar ter a reputação de indecente junto a quem tenta disfarçar a própria indecência sob a capa da virtude e da sabedoria. Note-se, nesse sentido, que o próprio Licino parece tomar alguma distância quando descreve a reação causada pela entrada

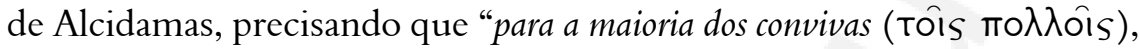
ele parecia ter feito coisa muito indecente", quase como se quisesse dizer que, em meio a semelhante festival de indecências, a aparição inopinada de Alcidamas não era uma. O fato é que, no coro ensaiado dos pilantras, regido pela conveniência e pela opinião, Alcidamas desafina.

No plano da narrativa que faz Licino, o "desajuste" de Alcidamas é representado pela própria dificuldade do anfitrião em encontrar para ele um espaço à mesa: a chegada inesperada de mais um conviva, que por si só causaria embaraço, torna-se ainda mais complicada com a recusa do próprio Alcidamas em tomar o lugar improvisado que arranjaram para ele, entre o gramático Histieu e o rétor Dionisodoro. ${ }^{72}$ Naquele momento, o cínico não perde também a ocasião de condenar, dirigindo-se ao dono da festa, a luxúria efeminada dos comensais que se banqueteiam deitados, quase de barriga pra cima, no meio de mantas e almofadas macias, ${ }^{73}$ enquanto ele

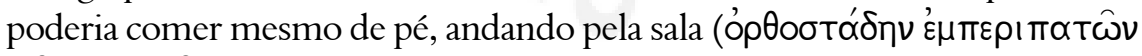

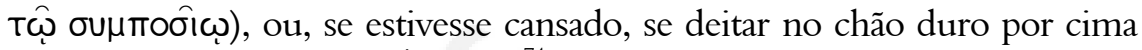

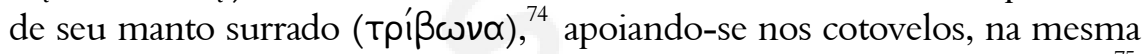
posição - ele faz questão de frisar - em que Héracles já tinha sido pintado. ${ }^{75}$

${ }^{72}$ Luciano, Banquete 13. Um detalhe aparentemente anódino deve ser notado: Aristêneto sugere que Alcidamas tome lugar entre um gramático e um rétor, duas categorias em que Diógenes costumava acusar um comportamento contraditório (D.L. VI, 28 e 47).

${ }^{73}$ Compare-se com o que diz Diógenes em Dion Crisóstomo, Or. VI, Diógenes ou A tirania, sobretudo nos passos 10-16. Cf. também Demóstenes Or. IV, Sobre a realeza 101-102.

${ }^{74} \mathrm{O}$ tríbon é uma das peças mais características da indumentária cínica (cf., por exemplo, D.L. VI, 77; 91; 93; Plutarco, An uitiositas ad infelicitatem sufficiat 3, 499c-d [SSR VB 153]; Filodemo, De stoicis, col.XVIII, 10 Dorandi; Luciano, Vida de Demônax 48) e a "dobradura do manto" ( $\delta ı \pi \lambda$ oû $\nu$ tòv т $\rho \beta \omega \nu \alpha)$ exprime em certos contextos a própria adesão ao cinismo (cf., por exemplo, D.L. VI, 13; 22; Pseudo-Diógenes, Carta VII, a Hicetas; Pseudo-Diógenes, Carta XV, a Antípatro; Pseudo-Diógenes, Carta XXX, a Hicetas 3).

${ }^{75}$ O próprio Licino reafirma a comparação um pouco adiante: Luciano, Banquete 14. Héracles é o patrono, uma espécie de "santo", do cinismo e, segundo alguns, o próprio fundador da escola; Juliano, Contra os cínicos ignorantes $8,187 \mathrm{c}$. 
Alcidamas escolhe assim - e a alegoria é plena de sentido - circular ( $\nu$ \&’ $V$ Kúk $\lambda \omega$ ) entre os filósofos sem lugar definido e adotar uma postura que nada tem a ver com a dos outros que, nesse aspecto, se equivalem sem qualquer distinção.

Mas há mais nesse começo: Alcidamas se demarca tanto dos convidados presentes - filósofos de todas as confissões, rétores, gramáticos e homens de letras em geral - como de um "ausente não convidado". Trata-se do estoico (ainda um estoico) Hetêmocles que não fora convidado para o banquete, justamente porque, cultivando com tamanho zelo a imagem do filósofo austero e sisudo, pouco dado às alegrias mundanas, Aristêneto julgara inútil convidá-lo. ${ }^{76}$ Hetêmocles envia-lhe então, como expressão do agravo de que se sentiu vítima, uma carta para ser lida durante a festa e diante de todos. Nessa carta, em meio a difamações visando comprometer os filósofos das outras escolas e uma profusão de citações mal alinhavadas com que buscava demonstrar a extensão dos seus conhecimentos, Hetêmocles manifestava seu ressentimento por ter sido preterido, ao mesmo tempo em que, roído pelo despeito e com o orgulho ferido, reafirmava seu desprezo pelos banquetes e pelas iguarias que normalmente são servidas nessas ocasiões. O final da carta é bombástico e revela a verdadeira natureza da austeridade e da parcimônia de seu autor:

Eu dei ordem a este valete para ele não aceitar nada para me trazer, caso tu lhe ofereças alguma coisa - uma porção de javali, de cervo ou um bolo de gergelim - como desculpa pelo banquete perdido! Que ninguém pense que eu o enviei por isso! ${ }^{77}$

Licino conta que, durante a leitura da carta, a vergonha banhava de suor o seu rosto e que ele só desejava que a terra o engolisse de uma vez. Ele via a audiência rir às expensas de um homem barbudo e já grisalho que, traindo o seu semblante respeitável, se prestava a um tal constrangimento. ${ }^{78}$ Luciano insiste aqui, mais uma vez, no descompasso profundo entre uma aparência que se quer ostentar e uma intenção ou desejo mais profundos como sintoma da hipocrisia e da incoerência dos filósofos profissionais. O efeito cômico decorre justamente do fato de que esse desejo acaba por vir à tona, traindo assim o exterior que devia camuflá-lo.

\footnotetext{
${ }^{76}$ Luciano, Banquete 28, 6-10.

${ }^{77}$ Luciano, Banquete 27.

${ }^{78}$ Luciano, Banquete 28.
} 
Se me detenho um pouco neste trecho do diálogo é por que ele, de algum modo, sublinha a superioridade de Alcidamas. Tanto o cínico (como parece claro na sequência) ${ }^{79}$ quanto o estoico Hetêmocles veem no banquete oferecido por Aristêneto a oportunidade para uma refeição farta, refinada e, melhor ainda, gratuita, da qual o velho Hetêmocles deve a contragosto se privar, uma vez que não foi convidado: obrigado a manter bem ou mal o pacto dos valores convencionais para usufruir da reputação e do prestígio que deles dependem, o que acaba sobressaindo no seu gesto é a sua impostura. Já Alcidamas, como bom cínico, recusando-se a transigir sobre a própria vontade e sem tampouco lançar mão de qualquer subterfúgio que pudesse dar a ela livre curso e ainda o livrasse de se expor a alguma reprovação, abraça voluntariamente a adoxía ${ }^{80}$ ele dispensa

${ }^{79}$ Luciano, Banquete 13-14; 16.
${ }^{80}$ Por exemplo, D.L. VI, 11; 93 . Note-se que Luciano, Sobre os retratos 17, coloca na boca de Licino a lembrança explícita do seguinte pensamento de Diógenes: “(...) Perguntado como alguém poderia se tornar famoso ( $\left.\varepsilon^{\prime} v \delta \circ \xi o s\right)$, ele [scil. Diogenes]

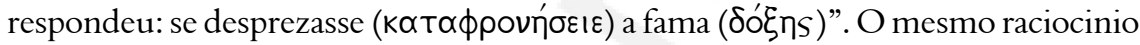
e mencionado por Teon, Progymnasmata V, p. 97, 11-22 Spengel (SSR V B 388): "Diógenes, o filósofo, perguntado por alguém como poderia se tornar famoso,

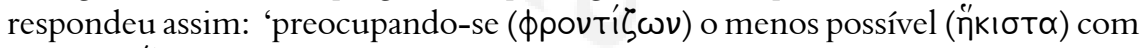
a fama ( $\delta \sigma^{\prime} \eta \varsigma$ )'”. Pode-se argumentar, por outro lado, que o cinico age no reverso dos valores convencionais apenas para ratifica-los. É aliás o que sugere o próprio Luciano, Leilão de filósofos 11, ao substituir a definição do cinismo dada por Apolodoro de Selêucia, na sua Ética (cf. D.L. VII, 121), como um "atalho para a virtude"

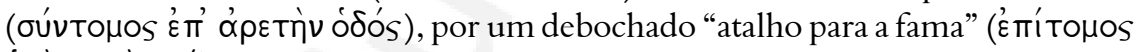

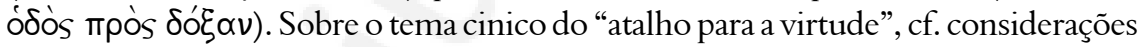
de Goulet-Cazé, op. cit., 1986b, p. 22-28. Na verdade, o ideal cínico da adoxía recobre os sentidos possíveis do termo: em primeiro lugar, o sentido passivo, como "má reputação" ou como "obscuridade (do nome)", em que o prefixo a- indica tanto um viés negativo da reputação quanto a sua simples ausência (os cínicos eram vítimas voluntárias da má reputação ou do desprezo); e, depois, o sentido ativo, como "desdém" ou "desprezo" (os cínicos desprezavam os valores comumente aceitos ou, propriamente, a opinião). Enfim, a adoxía é, a um só tempo, a consequência do fato de que os cínicos subordinam a opinião, enquanto elemento constitutivo do nómos, à realização afirmativa de uma virtude individual e "natural", e a condição necessária para o exercício do que poderíamos chamar de uma "pedagogia política”, que envolve as funções corretivas da denúncia social; trata-se portanto de uma condição necessária ao exercício pleno da parrhesía, outro atributo essencial do filósofo cínico (D.L. VI, 69). Assim, o alcance que os cínicos emprestaram à adoxia deve iluminar o que lemos em Estobeu II 31, 61 (SSR V B 315): “De Diógenes: quando tu te preocupas ( $\phi \rho \circ v \tau^{\prime} \zeta \zeta \varepsilon ı$ ) com outra pessoa, então tu te descuidas 
o protocolo do convite e, rompendo com as regras do decoro, penetra altivo no salão citando Homero: "Chega Menelau por vontade própria". O desconcerto provocado pela chegada de Alcidamas reforça-se então com mais esta ruptura cômica: o cínico legitima seu gesto, considerado vil e infame pelos outros, com o que há de mais elevado e sublime na cultura grega.

A ironia dos convivas, que aqui e ali respondem ao atrevimento de Alcidamas citando em voz baixa outros versos homéricos, ao contrário de diminuí-lo ou retaliá-lo, apenas torna mais espetacular a sua entrada, uma vez que reforça a comparação sugerida pelo cínico mesmo. Além disso, o adjetivo autómatos, que qualifica o gesto de Menelau (e que pode também ser entendido como "sem convite" ou, mais precisamente, no contexto homérico, como "sem ser chamado", funcionando portanto como um

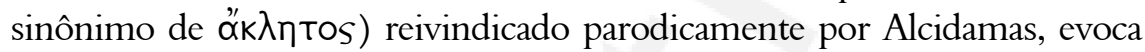
as virtudes cínicas da autodeterminação, da liberdade e da independência que a personagem, ainda que de modo enviesado (pelo menos segundo a moral tradicional), exibe. Não há como não perceber aí o eco de um termo correlato, a autárkeia, que perpassa toda a história do cinismo como um de seus conceitos fundamentais, determinando a condição sine qua non não apenas da liberdade, de que depende a eudaimonía, como também da prática efetiva da virtude: ${ }^{81}$ o sábio cínico é antes de tudo um autárkes: ${ }^{82}$ e essa sua característica explicaria, em boa medida, a preferência de Luciano por ele

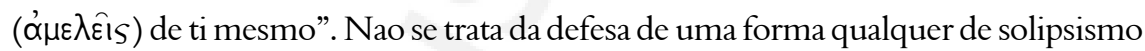
ou da proposição de um isolamento egoísta (confusão que Luciano parece também ter explorado: cf. Leilão de filósofos 10), mas, bem ao contrário, de determinar a ética individual como o campo necessário de exercício da virtude política. Nesse sentido, preocupar-se ( $\phi \rho \circ v \tau i ́ \zeta \varepsilon ı \nu)$ com um outro significa regular o próprio comportamento não pela virtude, mas pela opinião $(\delta o ́ \xi \alpha)$ que ele pode gerar. É claro que Luciano, com vistas à composição de um entrecho cômico, faz de Alcidamas uma personagem abusiva, mas ele é, do princípio ao fim do Banquete, uma espécie de antípoda dos outros filósofos convidados: os excessos e o desregramento das suas atitudes decorrem precisamente do fato de que suas intenções coincidem com o que delas se manifesta, enquanto a impostura dos outros, que se submetem inteiramente à opinião, reside numa tensão constante entre o que eles querem fazer (e fazem) e a maneira como eles querem ser percebidos.

${ }^{81}$ D.L. VI, 71.

${ }^{82}$ Cf., por exemplo, D.L. VI, 11; 78; 105; Gnomologium Vaticanum 743, n. 180 (SSR V B 241). Para outras referências e para uma análise do conceito, cf. Goulet-Cazé, op. cit., 1986b, p. 38-42, e Husson, op. cit., p. 76-83. Cf. enfim Rich, op. cit., p. 23-29 (republicado em Billerbeck, op. cit., p. 233-239). 
em outros contextos. ${ }^{83}$ Assim, da forma em que é narrado, o gesto de Alcidamas extrapola o exercício regrado e contido da autossuficiência em favor de uma autodeterminação transgressiva: naquilo que poderíamos chamar uma "economia das vontades", há sem dúvida excesso, mas de modo algum simulação ou fingimento.

O fato é que ninguém ousava falar abertamente (Ės Tò фavepóv),

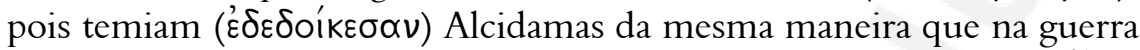
- e o banquete, no fim, se transforma numa verdadeira guerra $-{ }^{84}$ se deve temer um herói da envergadura de Menelau. O próprio Licino reitera a comparação lembrando que Alcidamas era realmente bom de

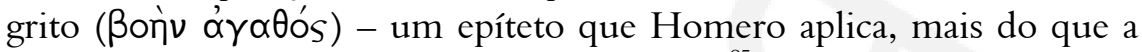
outros, a Menelau, como signo de bravura $-{ }^{85}$ e o mais barulhento de todos os cães. Nos termos do embate, entre o filósofo que é bom de grito $^{86}$ e os demais, que se limitam a murmurar (cf. o particípio

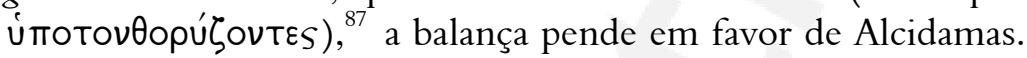

Não há dúvida de que Luciano visasse um efeito cômico ao assimilar a fórmula homérica às associações pejorativas que o nome da escola cínica sugere. Também não se pode excluir que essa referência a Homero tenha sido buscada em Platão. ${ }^{88}$ É, de fato, bastante provável que Luciano, ao elaborar a chegada inopinada de Alcidamas descrita por Licino no seu Banquete, tivesse em mente a maneira improvisada pela qual Aristodemo se introduz no banquete do Banquete platônico: ${ }^{89}$ Sócrates, para convencer o companheiro a se juntar a ele, vislumbra, com alguma ironia, a presença dos dois na casa de Agatão, citando um provérbio conhecido $^{90}$ e jogando ainda com o nome do dono da festa ('A $\gamma \alpha \dot{\theta} \theta \omega v$ ): "No banquete de homens excelentes, homens excelentes

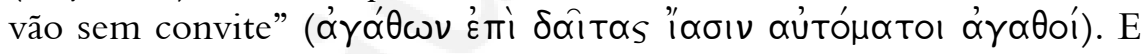

${ }^{83}$ Cf. Brandão, op. cit., 2001, p. 62-63.

${ }^{84}$ Cf., por exemplo, os termos empregados para introduzir a descrição da refrega

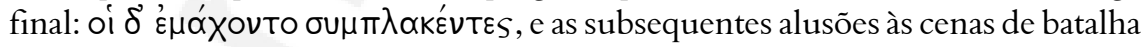
da Ilíada (XI, 233; XIII, 605): Luciano, Banquete 44.

${ }^{85}$ Homero, Ilíada II, 408.

${ }^{86}$ Cf. em D.L. VI, 44 a imagem do cínico que tem o hábito de gritar para dizer (¿ßßó по $\lambda \lambda \alpha^{\prime}$ เs $\lambda \varepsilon^{\prime} \gamma \omega \nu$ ) a virtude. Compare-se com Luciano, Banquete 16.

${ }^{87}$ Luciano, Banquete 12.

${ }^{88}$ Cf. nota 60 .

${ }^{89}$ Platão, Banquete 174b-d.

${ }^{90}$ Hesíodo, fr. 264 Merkelbach-West e Baquílides, fr.4.22 Snell-Maehler. 
acrescenta na sequência, de modo pouco preciso, que Homero traiu os termos deste provérbio ao fazer de Menelau, primeiro, um guerreiro

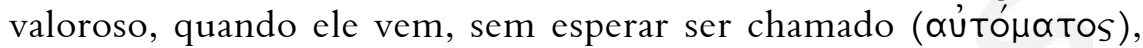
ao socorro de Agamêmnon; ${ }^{91}$ e, depois, qualifica-o de "lanceiro molenga" ( $\mu \alpha \lambda \theta \alpha$ kòs $\alpha і ̈ x \mu \eta \tau \eta ́ s) .{ }^{92}$ Ainda hesitante, Aristodemo reponde no mesmo registro homérico: "Na verdade, eu me arrisco a ser, não como tu dizes, mas, como em Homero, um sujeito de nada (申aû̀os) que vai num jantar na casa de um homem sábio (бoфoû ơvipós), sem

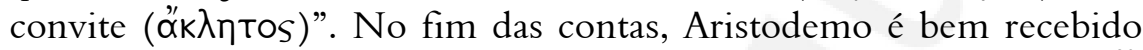
e junta-se sem problemas aos outros convidados na casa de Agatão. ${ }^{93}$ Em Luciano, a lógica da passagem aparece invertida. Mesmo guardando a ambiguidade que o Sócrates de Platão lê no Menelau de Homero, a entrada de Alcidamas no banquete parece sugerir uma outra versão daquele ditado: "Um homem melhor numa reunião dos piores chega sem convite".

Todavia, no quadro das referências homéricas, não parece provável que ao indicar que por isso ( $\pi \propto \rho$ '”), isto é, por ser realmente bom de grito e o mais barulhento de todos os cães, Alcidamas parecia ser o melhor

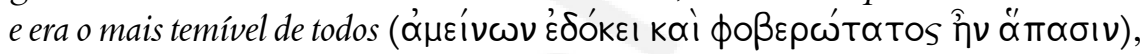
Luciano/ Licino quisesse acusar no cínico alguma incoerência entre seu discurso e sua ação, como se sua força residisse apenas no volume e na profusão desordenada de suas palavras - nos seus "latidos" -, ou seja, como se sua presença se resumisse no fim das contas a um inócuo "muito barulho por nada" (ou como se - poderíamos dizer para conservar o registro da metáfora - Alcidamas finalmente provasse que "cão que

\footnotetext{
${ }^{91}$ Homero, Ilíada II, 408.

${ }^{92}$ Homero, Ilíada XVII, 588. Na verdade, a expressão é dita por Apolo, que assume a aparência de Fénope, para reinfundir em Heitor o ânimo do combate. Em nenhum outro momento do poema, Menelau é referido como malthakós.

${ }^{93}$ A entrada de Alcidamas no Banquete de Luciano, pelos efeitos que provoca, talvez se compare melhor a de Alcibíades do que a de Aristodemo no Banquete de Platão (cf. 212c et seq.), muito embora em nenhum momento se diga que Alcibíades seja um ákletos. Além disso, diferentemente de Alcidamas, Alcibíades chega já bêbado, o que sem dúvida explica a grande algazarra que faz na entrada. Entretanto, uma de suas frases na entrada faz pensar na imagem do filósofo cínico, inclusive no cínico de Luciano (cf. 212e-213a): "Mesmo que vocês riam de mim, eu sei muito bem que

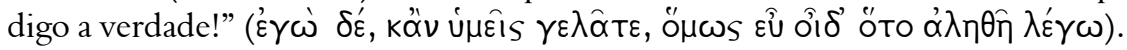


ladra não morde”). ${ }^{94}$ Nada no texto parece confirmar uma tal interpretação. $\mathrm{Na}$ verdade, é o próprio Licino quem observa que Alcidamas "era de fato muito ativo (évepyós), e, enquanto comia, discursava sobre o vício e a virtude", e que "sua atitude era conforme

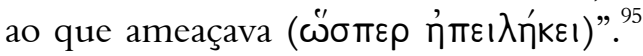

Nesse sentido, o breve discurso que Alcidamas profere em honra da noiva vem acompanhado de uma curiosa demonstração de

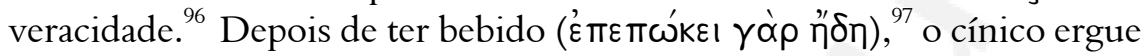
um brinde para desejar o que de melhor poderia suceder a uma jovem que se casa: que ela venha a ter um filho inflexível em seu vigor (ăтрєாтоS

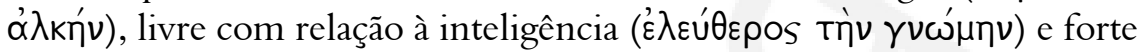

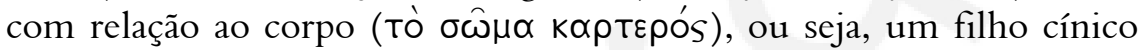

${ }^{94}$ A descrição de Alcidamas que Luciano coloca na boca de Licino nesta altura do texto traz à lembrança a figura de Tersites, personagem que intervém no canto II da Ilíada (cf. os versos 211-277) e que Demônax elogiava como um orador cínico ('Enṭive।

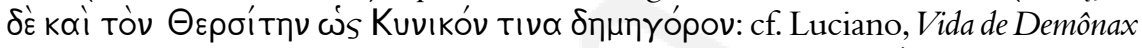
61). Este "anti-herói" homérico, cujas palavras, ditas a esmo ( $\mu \alpha \dot{\psi} \psi)$ contra os reis

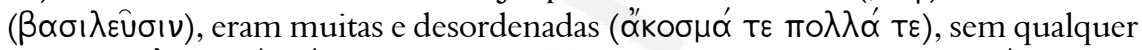

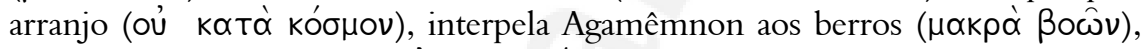

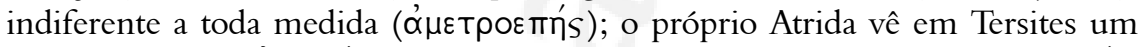

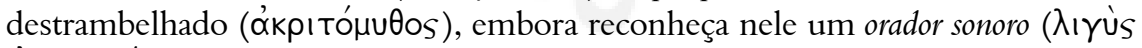

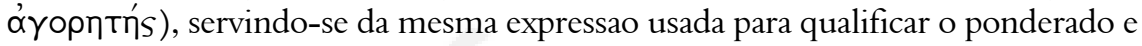
experiente Nestor (cf. Ilíada I, 247-248). O fato é que, tal como reproduzido pelo poeta, o discurso de Tersites é perfeitamente articulado e coerente, retomando aliás, em muitos pontos, os argumentos de Aquiles em sua altercação também com o chefe supremo dos gregos, no canto I (cf. Ilíada I, 148-171); sobre esse paralelismo, entre o discurso de Tersites e o de Aquiles, cf. Libânio, Elogio de Tersites 10. Sobre Tersites, em Homero e na literatura posterior, cf. Spina, op. cit., e, mais especificamente, sobre o "Tersites cínico" de que fala Demônax, cf. Flores-Júnior, op. cit., 2010, p. 227-250 e Flores-Júnior, op. cit., 2009/2010, p. 93-109.

${ }^{95}$ Luciano, Banquete 14.

${ }^{96}$ Luciano, Banquete 16.

${ }^{97}$ É possível que esta frase indique não exatamente a causa do discurso - Alcidamas discursa porque tinha bebido, isto é, o discurso seria o efeito, a consequência de sua embriaguez -, mas simplesmente a sequência das ações (um pouco antes, Aristêneto havia ordenado que lhe dessem um skyphos com vinho puro: cf. o final do passo 14): depois de ter bebido ou porque tinha acabado de beber o vinho que the ofereceram, ele toma a palavra. Note-se em todo caso que aqui Licino se limita a dizer que Alcidamas “já tinha bebido" (cf. o uso do mais-que-perfeito $\varepsilon \pi \varepsilon \pi \omega \hat{\omega} \kappa \varepsilon$ ), ao passo que, mais adiante, quando se refere à embriaguez geral dos convivas, a formulação é explícita: "A

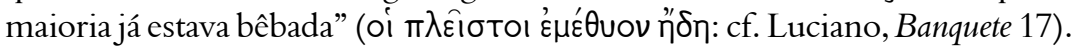


como o próprio Alcidamas (oios '̇ $\gamma \omega \dot{)}$ ). E, ao mesmo tempo que discursava $(\ddot{\alpha} \mu \alpha)$, ele ia tirando a roupa. Com esta cena, obviamente ridícula, Luciano mais uma vez força o traço no que é próprio do cinismo para compor um entrecho cômico: desnudar-se aos poucos - e Alcidamas já estava nu pela metade (cf. o advérbio $\mu \hat{\alpha} \lambda \lambda{ }^{\circ} \nu$ e, um pouco antes, o

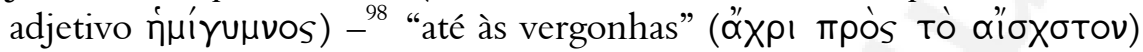
e, ainda por cima, durante um banquete de núpcias, como demonstração dos princípios de uma filosofia, não poderia senão provocar o riso dos

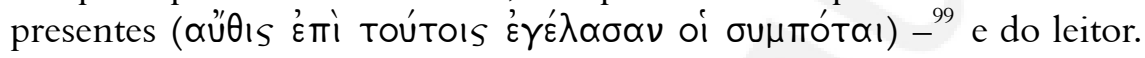
Ora, que o riso tenha sido o quinhão frequente das "performances" cínicas é algo que se pode não apenas supor (a partir da experiência mesma de leitura dos textos antigos preservados), mas que pode também ser comprovado com algumas passagens desses mesmos textos, que aludem explicitamente ao problema. ${ }^{100}$ Todavia, aqui, o ridículo da cena deixa entrever um outro elemento importante das ideias-força do cinismo: o fato de que o cínico toma o próprio corpo como prova última de sua coerência, e de que faz dele um terreno de verificação de sua doutrina, reconhecendo deste modo que toda virtude moral tem por fundamento - como a vida mesma - uma certa dimensão "fisiológica". ${ }^{101}$ Nas entrelinhas do humor provocado por Alcidamas, desenha-se então a mensagem original do cinismo, segundo a qual o único caminho que pode conduzir à felicidade - que constitui os votos que Alcidamas expressa em seu brinde a Cleântis - é aquele que conjuga, com um vigor inquebrantável, a liberdade do espírito e a força do corpo. Assim,

\footnotetext{
${ }^{98}$ Luciano, Banquete 14.

${ }^{99}$ Luciano, Banquete 16.

${ }^{100}$ Cf., por exemplo, D.L. VI, 54; 58; 91 . Um detalhe talvez significativo nesse aspecto é o fato de que das vinte e três ocorrências do termo $\gamma \dot{\varepsilon} \lambda \omega s$ e de seus cognatos, no Banquete, dez fazem alusão direta ao cínico, ou figuram em passagens em que ele claramente se destaca. Curiosamente, como parte do caráter que Licino lhe atribui, ele é o único dentre os filósofos que não suporta ser objeto de deboche: cf. Luciano, Banquete 19. A esse respeito, a "impressão pessoal" de Dudley, op. cit., revela algum ceticismo com relação a um uso filosófico do riso, e coloca-se, por isso, um pouco na contramão dos cínicos mesmos (e provavelmente do próprio Luciano): The stories about Diogenes are decidedly funnier than those Diogenes Laertius tells about other philosophers (p. 29, nota 2), e ainda: They belong rather to an anthology of Greek humour than a discussion of philosophy (p. 29).

${ }^{101}$ Cf., por exemplo, Dion Crisóstomo, Or. VI, Diógenes ou A tirania 8 et seq. Trata-se enfim do delicado problema da "dupla ascese" cínica, de que trata Goulet-Cazé, op. cit., 1986b. Cf., num sentido diferente, D.L. VI, 73.
} 
o escândalo cínico da nudez e da injúria (para retomar a expressão de Michel Foucault), encenado comicamente por Alcidamas, é na verdade o correlato de sua parrésia: o cínico se expõe no que expõe, atando num corpo que ele exibe uma verdade dita e vivida.

É, portanto, em vista de uma coerência estrita entre palavra e ação que Alcidamas se destaca de seus pares: a sua "fidelidade" a seu próprio discurso, o "ajuste" entre o que ele diz e o que ele faz inscrito em seu próprio corpo, corresponde enfim ao seu "desajuste" no conjunto dos filósofos com quem divide a cena. E é da perspectiva desse duplo antitético coerência/desajuste que sua intervenção no banquete deve ser compreendida. $\mathrm{Na}$ verdade, essa coerência rigorosa entre a vida do filósofo e a filosofia que ele prega, que faz convergir palavra e ação - texto proferido e gesto performático - para a composição de uma pedagogia original, constitui um dos aspectos doutrinais mais característicos do cinismo. ${ }^{102}$ Essa coerência seria ainda uma outra razão para a preferência de Luciano pelo modelo cínico, uma coerência inteiramente preservada na construção da personagem de Alcidamas, ainda que de modo hiperbólico com vistas a um efeito cômico. Assim, se há um desacordo risível na imagem de um filósofo que come - e Alcidamas come muito- ${ }^{103}$ enquanto discorre sobre vício e virtude, convém lembrar que esse desacordo só existe do ponto de vista de uma certa expectativa construída sobre a base de uma opinião comum. Porém, uma vez que o conteúdo mesmo deste discurso de Alcidamas não é reproduzido, nada sabemos do que de fato ele entende por vício e virtude: ${ }^{104}$ ao silenciar sobre a lógica que comanda sua "teoria”, Luciano inscreve o aparente desregramento de Alcidamas num ponto de suspensão moral.

Por outro lado, Licino nos informa que Alcidamas "debochava

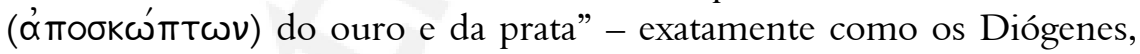

${ }^{102}$ Cf., para Diógenes, D.L. VI, 71. Cf. também a inusitada lição com a qual Crates converte Métrocles ao cinismo em D.L. VI, 94.

${ }^{103}$ Cf. Luciano, Banquete 13; 16.

${ }^{104}$ Ocorre aqui citar as palavras que Diderot faz dizer seu "sobrinho de Rameau", neste diálogo que é um verdadeiro monumento do cinismo moderno: Quanto aos vícios, a despesa ficou por conta da natureza. Quando digo vicioso, digo-o apenas para falar a vossa língua, pois se viéssemos a nos explicar, poderia ocorrer que chamásseis vício o que eu chamo virtude, e virtude o que chamo vício (cf. Diderot, op. cit., p. 362 para a citação). Sobre a influência de Luciano sobre Diderot, cf. Romano, op. cit., p. 57-113. Cf. ainda a seção "Cinismo ilustrado", in: Torres Filho, op. cit., p. 53-69. 
Crates e Menipos dos Diálogos dos mortos -, e perguntava a Aristêneto que valor podia haver em taças tão elegantes cuja serventia não é maior do que a de copos de barro. ${ }^{105}$ Emerge aqui o critério de utilidade próprio dos cínicos, fundado numa razão implacável, hipertrofiada talvez, inteiramente voltada para a constituição de uma espécie de "riqueza regressiva" - tanto mais rico se é quanto menores são as posses e, sobretudo, os desejos e as necessidades- ${ }^{106}$ e que constitui um dos aspectos de sua "ética do mínimo". ${ }^{107}$ O fato de que Alcidamas adote apenas parcialmente essa "ética do mínimo" contribui para o caráter burlesco de seu comportamento, mas ele ainda se distingue dos demais: correndo atrás dos garçons, Alcidamas também se empanturra com as iguarias servidas, ${ }^{108}$ como a maioria dos convivas, que chegam mesmo a se estapearem por causa delas; ${ }^{109}$ mas, diferentemente do rétor Dionisodoro e do platônico Íon, que no tumulto da refrega tentam roubar uma taça, ${ }^{110}$ o cínico não faz caso dos utensílios dispostos nas mesas, nem do décor

\footnotetext{
${ }^{105}$ Luciano, Banquete 14. O mesmo tipo de argumento aparece em O cínico 9.

${ }^{106}$ Esse princípio, que encontramos já em Antístenes (cf., por exemplo, Xenofonte, Banquete IV, 34 et seq.), evolui a partir de Diógenes: cf., por exemplo, para Diógenes: D.L VI, 37; 50; 51; Epiteto I, 24, 6-9 (SSR VB 265); Estobeu III, 10, 62 (SSR VB 240); IV, 31, 88 (SSR V B 220); IV, 32, 11 (SSR V B 223); IV, 32, 12 (SSR V B 224); IV, 32, 19 (SSR V B223); IV,33, 26(SSR VB225); Gnomologium Vaticanum 743 n. 180 (SSRVB241) e n. 182 (SSR V B 361); e para Crates: D.L. VI, 85; 87; 96; Simplício, In Epicteti enchiridion commentarium 5 (SSR VH 6); Gnomologium Vaticanum 743, n. 387 (SSR VH4); Gregório Nazianzeno, Carmina I 2, 10 v. 228-243 (SSR V H 8). Trata-se, enfim, de uma pobreza infinita, conforme a estimulante análise de Michel Foucault: La pauvreté cynique est une pauvreté infinie. Elle est réelle, elle est active et elle est infinie, ou indéfinie, en ce sens qu'elle ne s'arrête pas à un stade considéré comme satisfaisant, parce que, à ce moment-là, on pourrait considérer qu'on esten somme livre de tout ce qui est superflu. Elle cherche encore et toujours des dépouillements possibles. C'est une pauvreté inquiète, une pauvreté insatisfaite d'elle-même qui s'efforce toujours d'atteindre de nouvelles limites, jusqu'à rejoindre le sol de l'absolument indispensable (Foucault, op. cit., p. 238).

107 “'O que tem muito valor', dizia Diógenes, 'se vende por nada, e vice-versa. Assim, uma estátua é vendida por três mil dracmas, enquanto por dois tostões de cobre se compra um saco de farinha"” (D.L. VI, 35). "A alguém que lhe mostrava um

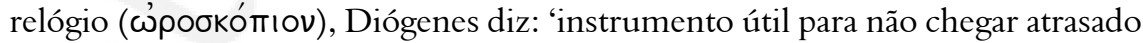
ao jantar" (D.L. VI, 104). Desenvolvo a ideia de uma "ética do mínimo" no cinismo antigo em Flores-Júnior, op. cit., 2006, p. 647-677.

${ }^{108}$ Luciano, Banquete 16.

${ }^{109}$ Luciano, Banquete 42-43.

${ }^{110}$ Luciano, Banquete 46.
} 
elegante em que o banquete evolui. ${ }^{111}$ De certa forma, o excesso de Alcidamas vai na boa direção, pois ele reconhece o que de fato é necessário para viver, se não em quantidade, ao menos em categoria. No quadro da descrição de Licino, que não poupa nenhum dos "sábios" daquele Museu, Alcidamas transforma em oportunismo aparentemente desregrado o conselho pragmático de Diógenes que, consultado sobre a que horas convém fazer as refeições, responde: "Se tu és rico, quando quiseres, se pobre, quando puderes". ${ }^{112}$ Enquanto homem autómatos (e por isso, em alguma medida, autárkes), e recusando a necessidade de acomodar as aparências em nome de uma reputação qualquer, Alcidamas apenas aproveita ostensivamente uma ocasião de se regalar.

Cabe nesse ponto notar um detalhe importante, que parece confirmar que o cínico age mesmo segundo outros princípios, colocando-se ostensiva e deliberadamente à margem dos códigos convencionais do ambiente que frequenta: "Como ( migrava em direção a pastagens mais fartas e acompanhava o percurso dos que faziam circular os pratos". ${ }^{113}$ Com esta comparação irônica de Licino, Luciano sugere no comportamento da personagem o exercício de um certo "relativismo cultural" que desloca o seu ponto de vista e os critérios que guiam sua ação. Convém lembrar que, segundo Heródoto (e o recurso a modelos clássicos por Luciano é bem conhecido, como provam aliás as alusões a Homero mencionadas acima), ${ }^{114}$ os citas representariam um caso à parte entre os povos bárbaros das regiões ao norte do Ponto-Euxino, considerados normalmente como muito primitivos e intelectualmente inferiores: os citas - dentre os quais parece fazer figura de exceção o lendário sábio Anácarsis que, segundo a tradição, fora

${ }^{111}$ Cf. a propósito as diversas versões para a anedota em que Diógenes joga fora sua caneca quando vê uma criança usar as mãos em concha para beber: Sêneca, Carta a Lucílio 90, 14; Plutarco, De profectibus in virtutem 8, 79e; D.L. VI, 37; Gnomologium Vaticanum 743, n. 185; Jerônimo, AdversusJovinianum II, 14; Simplício, In Epictetienchiridioncommentarium 32; Basílio, Carta I, 4; Pseudo-Diógenes, Carta VI, a Crates; Basílio, Carta XIII, a Apólexis (cf. os textos reunidos por Giannantoni em SSR V B 158-161). Sobre essas diferentes versões, cf. análise detalhada de Goulet-Cazé, op. cit., 1992, p. 3880-4048 (cf., sobretudo, p. 4029-4036).

${ }^{112}$ D.L. VI, 40. A mesma anedota é atribuída a Bíon de Borístenes (cf. Gnomologium Vaticanum 743, n. 156 = F 80 Kindstrand), filósofo que viveu no séc. IV-III a. C. e que foi cínico pelo menos durante um período de sua vida. Cf. também D.L. VI, 56.

${ }^{113}$ Luciano, Banquete 13.

${ }^{114}$ Consulte-se a propósito o monumental estudo de Bompaire, op. cit.(reed.: Paris: Les Belles Lettres/ Nino Aragno, 2000). 
acolhido amigavelmente por Sólon em Atenas-, ${ }^{115}$ ainda que desprezados sob certos aspectos, eram reconhecidos e admirados justamente pela eficácia de seu nomadismo, que os colocavam ao abrigo do ataque de inimigos e invasores. ${ }^{116}$ Heródoto aliás atribui a esse

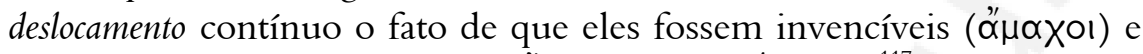

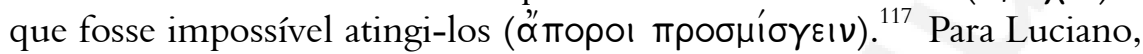
os citas - e, em especial, Anácarsis (mas também Tóxaris) - incarnam uma forma de alteridade que coloca em xeque a moral e as virtudes

${ }^{115}$ D.L. I, 101-102.

${ }^{116}$ O nomadismo dos citas é também mencionado por Luciano, de modo sem dúvida positivo, em Elogio da mosca 9: "Ela não instala seu ninho ou seu teto em um só lugar,

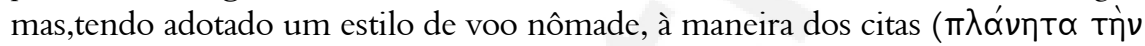

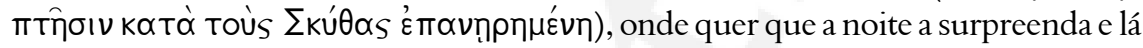
que ela faz seu lar e sua cama. De fato, como eu dizia, ela não faz nada no escuro, nem acha certo se esconder para fazer o que quer que seja, nem pensa fazer nenhuma indecência que, feita às claras, lhe traria o opróbrio". Ainda que este breve e insólito encômio seja na verdade um paígnion, isto é, um jogo sofístico, ou um exercício retórico escolar (como sugere Bompaire in Lucien, op. cit., 1993, p. 76), os termos com os quais Luciano o constrói devem reter nossa atenção. Assim, se o elogio de um ser ádoxon constitui um dos modelos possíveis conhecidos desse tipo de exercícioDemétrio, De elocutione, cap. 170, menciona um Elogio do purêde lentilhas (cf. Bompaire, loc. cit.) -, na passagem citada o eco de certos tópoi da literatura cínica não passa despercebido. Primeiro, o nomadismo da mosca, assimilado ao dos citas, evoca o tema cínico do cosmopolitismo: o filósofo cínico tem a terra inteira como morada e qualquer lugar the convém para dormir (cf., por exemplo, D.L. VI, 63; 98); além disso, a "moral" atribuída à mosca, que a leva a agir sempre abertamente, obedece à mesma lógica que entre os cínicos corrobora para redesenhar as fronteiras entre o público o privado (cf., por exemplo, D.L. VI, 69), o que poderia de algum modo

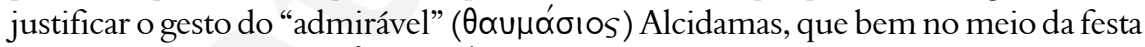

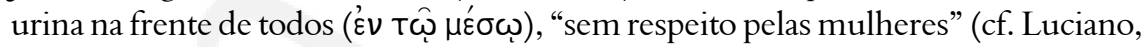
Banquete 35). Cf., a propósito do cosmopolitismo cínico Moles, op. cit., 1993, p. 259 280; Moles, op. cit., 1995, p. 120-158; Schofield, op. cit., p. 141-145.

${ }^{117}$ Eis o que diz Herótodo: "O Ponto-Euxino, contra o qual Dario devia marchar, abriga, excetuados os citas, as populações menos evoluídas que existem: dos povos desta região nada há para assinalarmos no que diz respeito à sabedoria, nem sabemos de homem inteligente que tenha aí nascido, fora os citas e Anácarsis. Se nós reconhecemos que o maior dos problemas humanos foi muito sabiamente solucionado pela gente cita, quanto ao resto eu na verdade não a aprecio. A importante questão que eles resolveram é o modo de impedir que qualquer um que venha até eles lhes escape ou os alcance, se eles não quiserem ser alcançados. Pois entre eles não se constroem cidades ou muralhas, e todos são arqueiros a cavalo, que levam 
"naturais" dos gregos. ${ }^{118}$ Com a atitude de Alcidamas, conforme descrita por Licino, o deslocamento geográfico dos citas transmuta-se (comicamente, sem dúvida) em deslocamento moral, embaralhando as noções de vício e virtude: assim como os povos nômades nunca estão lá onde se pretende atacá-los, também Alcidamas parece esquivar-se do tipo de censura a que se expõem os outros, justamente porque ele se recusa abertamente e de antemão a jogar o jogo do banquete pelas regras impostas. Deste modo, o cínico leva às últimas consequências, investindo-se delas na própria ação, a "antropologia comparativa" dos sofistas que já haviam constatado, frente à regularidade biológica da espécie humana, a diversidade e a relatividade dos nómoi dos diferentes povos. Assimilado aos citas, Alcidamas não faz mais do que adaptar - e a adaptação às circunstâncias é um motivo cínico dos mais importantes $-{ }^{119}$ para o contexto do banquete de que ele participa sem convite, o ponto de vista que Diógenes, interpretando o mito de Édipo, exprime sobre o incesto: "Mas os galos não se incomodam com essas coisas, nem os cães, nem os asnos; e nem mesmo os persas, que no entanto são tidos como os melhores de toda a Ásia!". ${ }^{12}$

suas casas consigo, vivendo não da semeadura da terra, mas de seus rebanhos, com seus lares atrelados às carroças. Como se poderia lutar contra pessoas assim, ou atingi-las?" (Heródoto IV, 46). Sobre o assunto, consulte-se Hartog, op. cit., p. 97-116. É igualmente interessante notar que Licino, que já havia observado o medo que Alcidamas inspirava nos outros filósofos, insiste na dificuldade de combatê-lo e no perigo que ele representava para todo mundo: Luciano, Banquete 12; 44; 45.

${ }^{118}$ Cf., por exemplo, o entrecho de Anácarsis ou Sobre a ginástica e de Tóxaris ou Sobre a amizade, bem como a menção aos citas no quadro da diversidade das práticas religiosas em diferentes culturas em Zeus Trágico 42. Nesse contexto, o breve discurso O cita ou o cônsul deve ser considerado à parte, em vista dos prováveis objetivos de seu autor: trata-se aí não do relativismo decorrente de um ponto de vista excêntrico mas da imagem do bárbaro aculturado, permeável aos modos de uma civilização "superior", que é evocada no quadro de uma capitatio benevolentiae por um orador que discursa em terra estrangeira. Na pequena biografia que Diógenes Laércio lhe consagra, Anácarsis representa o sábio que, confrontado com uma cultura estrangeira que ele julga melhor, se esforça em seguida por transmiti-la a seus concidadãos. Um outro detalhe transmitido por Diógenes Laércio, e que aproxima Anácarsis dos cínicos, é que ele também praticava a parrésia, dando origem assim à expressão proverbial "falar como um cita" (D.L. I, 101-105). Enfim, assinale-se que o narrador das Narrativas verdadeiras menciona Anácarsis como um dos poucos bárbaros que ele encontra na Ilha dos Bem-aventurados (Luciano, Narrativas verdadeiras B 17).

${ }^{119}$ D.L. VI, 63 e Estobeu II 8, 21 (SSR V B 148).

${ }^{120}$ Dion Crisóstomo, Or.X (9), Diógenes ou Sobre os domésticos 30. 
A transgressão afirmativa de Alcidamas rompe então com o pacto da moral perversa subscrita pelos outros, causando evidentemente um grande incômodo, que o dono da festa tenta contornar lhe oferecendo, primeiro, uma grande taça bem cheia de vinho puro e, depois, um generoso bolo: ${ }^{121}$ indiferente a qualquer prazer "simbólico" que possa advir da eudoxía, ${ }^{122}$ só o essencial para a sua existência biológica - vale dizer: comida e bebida - parece interessar a Alcidamas. Seja como for, ele incomoda constantemente e indistintamente a todos os presentes.Também neste aspecto, o retrato do cínico pintado por Luciano espelha (com a distorção própria de uma obra satírica, convém insistir) o que encontramos sobre o cinismo em outras fontes. Nesse caso, aquilo que Licino identifica textualmente como o principal - se não o único - efeito da presença de Alcidamas, ou seja, o incômodo e a perturbação que deliberadamente ele causa, é o que o próprio Diógenes reivindica como uma das tarefas do filósofo, conforme se deduz de uma conhecida passagem de Temístio: ${ }^{123}$

[Diógenes, a respeito de Platão:] "Que utilidade terá para nós um homem que, filosofando já há tanto tempo, jamais perturbou alguém

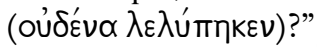

Lembrando que o próprio Platão considerava que Diógenes era

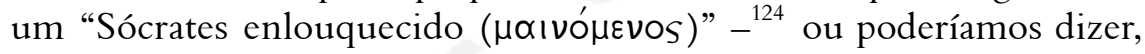

${ }^{121}$ Luciano, Banquete 14 e 17 . Se os cínicos manifestavam alguma reserva com relação ao consumo do vinho (cf., por exemplo, D.L. VI, 90 e Antonius et Maximus, De ebrietate 302, apud Paquet, op. cit., p. 94), mas, ao que parece, sem recusá-lo radicalmente (cf. D.L. VI, 66), e mesmo se contentando de ordinário com uma nutrição mais rústica e frugal (cf., por exemplo, Xenofonte, Banquete IV, 41; Dion Crisóstomo, Or. VI, Diógenes ou A tirania 12-13; D.L. VI, 55; 85-86), eles não dispensavam sistematicamente os produtos de uma culinária mais sofisticada, tais como bolos e pães de mel (cf. D.L. VI, 56; Gnomologium Vaticanum 743, n. 188 [SSR V B 189]; Estobeu III 17, 15 [SSR V B 494]; Luciano, Vida de Demônax 52).

${ }^{122}$ Da mesma maneira, Anácarsis não compreende o valor da coroa de louros oferecida aos vencedores dos jogos: cf. Luciano, Anácarsis ou Sobre a ginástica 9-10. No Banquete, Luciano "exagera" certos aspectos do cinismo que outras fontes nos obrigam a nuançar: cf., por exemplo, Dion Crisóstomo, Or. VI, Diógenes ou A tirania 1-5.

${ }^{123}$ Temístio, Da alma, apud Estobeu III 13, 68 (SSR V B 61).

${ }^{124}$ D.L. VI, 54. Esta passagem, que não consta em todos os manuscritos da obra de Diógenes Laércio, é referida também por Eliano, História vária XIV 3, figurando ainda em duas antologias bizantinas: Gnomologium Vaticanum 743, n. 442 e Cod. Vat. Gr. 1144, f. 232r (cf. SSR V B 59). 
apenas pelo efeito da sugestão (que obviamente não é confirmada pelo vocabulário grego), um "Sócrates perturbado"? -, caberia observar que é justamente em oposição a um "modelo dominante" de filósofo que o cínico afirma a sua ideia de filosofia: o comando é perturbar - e de preferência lá onde a ordem parece melhor estabelecida - para despertar os homens de seu torpor moral e da inércia dos comportamentos ensaiados a que a submissão à dóxa lhes força. Contudo, se aquele que abraça o cinismo "escolhe ser a má consciência de sua época e ser aquele por quem o escândalo chega", ${ }^{125}$ ele age não por horror à humanidade, mas por filantropia: "Diógenes dizia: 'os outros cães mordem seus inimigos, mas eu mordo os meus amigos, a fim de salvá-los" "126 Nos termos do próprio Luciano, o cínico pretende ser um "liberador dos homens e um médico das paixões, um profeta da verdade e da franqueza". ${ }^{127}$ A esta altura, a comparação com Menelau reivindicada por Alcidamas (e confirmada por Licino) ganha em profundidade. $\mathrm{Na}$ passagem de Homero a que o cínico alude, nós lemos: "E chega Menelau sem ser chamado, pois sabia no fundo que o irmão precisava". ${ }^{128}$

O incômodo que o cínico provoca, e que ele se dá por missão, constitui portanto um socorro para os homens. E se é assim, é porque existe nesse incômodo um valor de denúncia, o que explicaria ainda o uso, por Luciano, da imagem dos filósofos tradicionalmente ligados ao cinismo na expressão de sua crítica da cultura. ${ }^{129}$ Nesse sentido, a figura de Alcidamas no Banquete corresponde ao Menipo que aparece nos Diálogos dos mortos. O "cão Menipo", considerado um "perfeito chato"

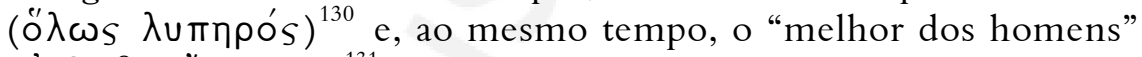

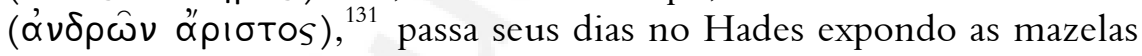
daqueles que, mesmo depois de mortos, continuam a lamentar a perda do typhos - renome, beleza, riqueza e outros prazeres ridículos e ilusórios

\footnotetext{
${ }^{125}$ Cf. Goulet-Cazé, op. cit., 1992 a, p. 9.

${ }^{126}$ Estobeu III 13, 44 (SSR V B 149). Sobre a "missão" do cínico, cf. textos reunidos em SSR V B 264-271.

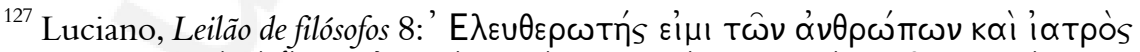

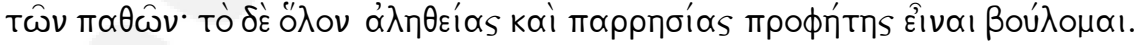

${ }^{128}$ Homero, Ilíada II, 408.

${ }^{129}$ Cf. Brandão, op. cit., 2001, p. 62.

${ }^{130}$ Luciano, Diálogos dos mortos 3 (2), 1.

${ }^{131}$ Luciano, Diálogos dos mortos 20 (10), 2.
} 
- que cultivavam em vida. ${ }^{132}$ Esse comportamento paradoxal, que combina duas qualidades aparentemente contraditórias, excelência e "chatice", instala o cínico numa posição marginal de onde, justamente, o exercício da denúncia e da crítica se cumpre melhor. Assim, da mesma maneira que Alcidamas, num banquete de núpcias, se recusa a tomar lugar à mesa dos filósofos, Menipo também, no reino dos mortos, onde as máscaras caem para revelar a realidade dura dos ossos e das ilusões, ${ }^{133}$ recusa o convite de Sócrates para se juntar a ele e a seu séquito de jovens bonitões: "Não, por Zeus! Estou indo lá para junto do Creso e do Sardanápalo. Vou morar perto deles. Ao que parece, vou rir - e não vai ser pouco - ouvindo as suas choradeiras". ${ }^{134}$

${ }^{132}$ Luciano, Diálogos dos mortos 6 (20), 4; cf. também Luciano, Diálogos dos mortos 12 (14), 6. Sobre a importância do conceito de typhos na tradição cínica, cf. Flores-Júnior, op. cit., 1999b, p. 421-429, e a análise mais completa e aprofundada de Caizzi, op. cit.

${ }^{133}$ Cf. Brandão, op. cit., 1996, p. 32-37.

${ }^{134}$ Luciano, Diálogos dos mortos 20 (6), 6 (tradução de M. C. C. Dezotti). É interessante notar que, naquele que parece ser o único texto antigo em que há uma referência explícita e direta de Diógenes a Sócrates, o que encontramos é, não um elogio ou uma reverência, mas uma crítica mordaz: "Diógenes dizia que o próprio Sócrates levava

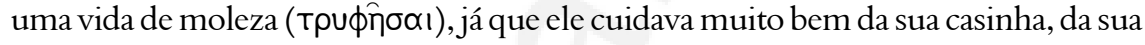
caminha e de um par de chinelos alinhados que acontecia de ele usar de vez em quando"(Eliano, História vária IV 11 [SSR VB 256]). Tudo se passa como se Diógenes resistisse a tomar parte numa tradição cuja herança tantos outros filósofos reivindicavam, a exemplo de certos estoicos (cuja escola é comumente associada ao cinismo) que "queriam, também eles, serem chamados “socráticos" (Filodemo, De stoicis col. XIII 3-4 Dorandi). De modo análogo, a relação entre Antístenes e Diógenes (e aqui interessa pouco se essa relação é um dado histórico ou uma invenção gestada no ambiente das "sucessões de filósofos") parece ter se caracterizado mais por um embate ativo entre duas inteligências solidárias do que pela transmissão passiva (e pacífica) de uma doutrina segundo as regras da obediência discipular: cf. Dio Crisóstomo, Or. VIII, Diógenes ou sobre a virtude 1-4; D.L. VI, 18-19; 21 (sobre o assunto, cf. detalhado estudo de Fuentes González, op. cit., 2013, p. 225-267). Nesse sentido, mesmo a expressão "escola cínica" deve ser utilizada com alguma prudência: trata-se antes de uma orientação ética geral que recebeu, no processo de sua constituição histórica, a marca da personalidade e do temperamento de seus adeptos (cf., por exemplo, D.L. VI, 15). Na ausência de um sistema de dogmas bem definidos, o cinismo seria menos uma "escola", no sentido institucional do termo, do que um movimento. Parece bastante verossímil, portanto, que Luciano, que tanto combateu o sectarismo surdo e as lucubrações mirabolantes de muitas escolas filosóficas, visse no cinismo a expressão de uma inteligência soberana, de uma autonomia e de uma liberdade de espírito comprometidas genuinamente com uma verdade "útil", tornando o seus adeptos capazes de, por assim dizer, "cortar na própria carne", a fim de fazer triunfar a lucidez do indivíduo contra a dóxa estanque e contra os devaneios do typhos. 
Por outro lado, se no Hades é o Cão Menipo que fustiga e debocha dos Cresos, Sardanápalos, Midas, Alexandres e de toda a corja dos insensatos (e mesmo de Sócrates), enquanto que no banquete em que se introduz por infração, o cínico Alcidamas é, ao contrário, objeto do escárnio (no mais das vezes velado e medroso) de outros insensatos, comandados pelo charlatanismo e pelo enfatuamento, no fundo é sempre a derrisão que comanda, e a variação e a aparente inversão dos juízos sobre o cinismo não é mais do que uma "ilusão de ótica" que Luciano manobra com um único objetivo. ${ }^{135}$ Vistos da perspectiva do conjunto de sua poética, o método revela a sua unidade: o gesto excêntrico que provoca o riso e o gesto excêntrico que provoca com o riso convergem para o mesmo ponto: ambos acusam e denunciam, trazendo-os à luz, o mecanismo dos comportamentos irrefletidos e a ignomínia a que eles conduzem - e todo riso, como explicou Bergson, advém no geral da descoberta repentina de um raideur de mécanique. ${ }^{136}$ Assim, ainda que a ação do cínico pareça se dissolver no riso, ao expor-se insolente e ostensivamente ao ridículo, o cínico expõe ao ridículo aqueles mesmos que buscam esconjurar pelo riso a infâmia, a vergonha e o constrangimento. No fim das contas, ocupando qualquer um dos dois termos dessa equação complexa, o filósofo cínico é um cão que morde em meio ao riso. ${ }^{137}$

A simples descrição do final do banquete, nas palavras mesmas de Licino, já valeria a conclusão e, como julgo, a confirmação, do que pretendi defender aqui. Como mencionei no começo, a festa dos sábios acaba em grossa pancadaria, cujo começo e motivo não interessa reconstruir aqui. Encontramos nesse inusitado combate de intelectuais a figura de Alcidamas mais uma vez em relevo, provando em outros domínios a sua habilidade em perturbar:

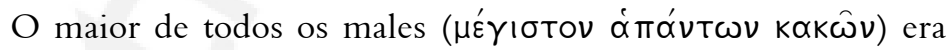
Alcidamas: depois de derrotar os seus próprios adversários, ele começou a bater em qualquer um que atravessasse o seu caminho. E saiba que muitos teriam morrido se o seu bastão não se tivesse quebrado (...). ${ }^{138}$

\footnotetext{
${ }^{135}$ D.L. VI, 54; 58. Sobre o assunto, vejam-se alguns elementos de reflexão em FloresJúnior, op. cit., 1999a, p. 149-158. Veja-se enfim Goulet-Cazé, op. cit., 1993, p. 273-313. ${ }^{136}$ Cf. Bergson, op. cit., p. 7-8: Ce qu'il y a de risible (...) c'est une certaine raideur de mécanique là où l'on voudrait trouver la souplesse attentive et la vivante flexibilité d'une personne.

${ }^{137}$ Luciano, Dupla acusação 33.

${ }^{138}$ Luciano, Banquete 45.
} 
Ao fim da peleja, enquanto o médico Dionico corria de um lado para o outro acudindo a quem pudesse e, enquanto a maioria dos comensais, em péssimo estado, era evacuada em macas, uns gemendo de dor, outros vomitando pelo caminho, "Alcidamas ficou no mesmo lugar, pois ninguém foi capaz de arredar o homem de lá: ele se atirou de uma só vez num sofá e ali dormia atravessado". ${ }^{139}$

Que fique, no fecho destas linhas, a cena final da narrativa de Licino, que traz a imagem de um homem que parece dormir o sono tranquilo dos justos. Da sua entrada espetacular, sem convite e resoluto, até este providencial sofá que recolhe o corpo cansado, mas ileso, de um guerreiro de valor, acredito que as evoluções de Alcidamas na casa de Aristêneto deixam no leitor do Banquete a mesma impressão que acredito ter sido a opinião de Luciano ao construir a personagem: que o filósofo cínico é de fato o melhor de todos. E para a legenda do quadro recorro (mais uma vez, num contexto semelhante) ${ }^{140}$ a uma outra máxima de Diderot, que bem pode definir as razões de uma simpatia genuína, do tipo da que fez vibrar na mesma frequência, ainda que em alturas diferentes, o gênio do escritor de Samósata e a verve do exilado de Sínope (e ainda a de Cioran, que foi de onde parti): "Prefiro um crime atroz e momentâneo a uma corrupção policiada e permanente, um violento acesso de febre às manchas da gangrena". ${ }^{141}$

\section{Referências}

BERGSON, H. Le rire. Paris: Quadrige/ P.U.F., 1993.

BIELER, J. Über die Echtheit des Lucianischen Dialogs Cynicus. Hildesheim: Gerstenberg, 1891.

BILLERBECK, M. Le cynisme idéalisé d'Épictète à Julien. In: GOULET-CAZÉ, M.-O.; GOULET, R. (Org.). Le cynisme ancien et ses prolongementes. Paris: P.U.F., 1993, p.319-338.

BILLERBECK, M. Die Kyniker in der modernen Forschung. Amsterdam: B. R. Grüner, 1991.

BOMPAIRE, J. Lucien écrivain: imitation et création. Paris: De Boccard, 1958.

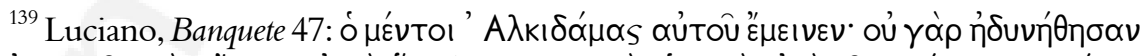

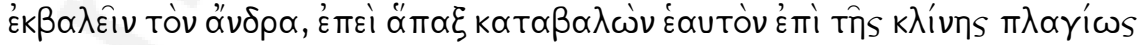
¿Кর̊́ $\theta \varepsilon \cup \delta \varepsilon$.

${ }^{140}$ Cf. Flores-Júnior, op. cit., 1998/1999, p. 133.

${ }^{141}$ Apud Romano, op. cit., p. 61.
} 
BRANDÃO, J. L. Diálogos dos mortos sobre os vivos. In: LUCIANO. Diálogos dos mortos. Tradução e notas de Maria Celeste Consolin Dezotti, São Paulo: Hucitec, 1996, p. 11-43.

BRANDÃO, J. L. A poética do Hipocentauro: literatura, sociedade e discurso ficcional em Luciano de Samósata. Belo Horizonte: UFMG, 2001.

BRANDÃO, J. L. A Grécia de Machado de Assis. Kléos, Rio de Janeiro, vol. 5/6, p. 125-144, 2001/2002.

BRANHAM, R. B. Unruly eloquence: Lucian and the comedy of traditions. Cambridge, Mass.: Harvard University Press, 1989.

CAIZZI, F. D. Tûфos: contributto alla storia di un concetto. Sandalion, Sassari, vol. 3, p. 53-66, 1980.

CASTER, M. Lucien et la pensée religieuse de son temps. Paris: Les Belles Lettres, 1937.

CIORAN, E. M. Joseph de Maistre: ensaio sobre o pensamento reacionário. In: CIORAN, E. M. Exercícios de admiração: ensaios e perfis. Prefácio e trad. José Thomaz Brum. Rio de Janeiro: Rocco, 2001, p. 1-47.

DIDEROT, D. O sobrinho de Rameau. Trad. M. Chauí. In: VOLTAIRE; DIDEROT, col. Os pensadores, vol. XXIII. São Paulo: Abril, 1973, p. 337-380.

DILLON, J. M.; LONG, A. A. (Org.). The question of "eclecticism": studies on later Greek philosophy. Berkeley: University of California Press, 1988.

DIOGENES LAERTIUS. Vitae Philosophorum. Edit M. Marcovich. Stuttgart/ Leipzig: Teubner, 1999 (2. vols.).

DIOGENES LAERTIUS. Vies et doctrines des philosophes illustres. Traduction française sous la direction de M.-O. Goulet-Cazé. Paris: La Pochothèque, 1999.

DIOGENES LAERTIUS. Diogenis Laertii Vitae Philosophorum. Recognovit brevique adnotatione critica instruxit H. S. Long. Oxford: Clarendon Press, 1964 (2 vols.). DUDLEY, D. R. A history of Cynicism: from Diogenes to $6^{\text {th }}$ century A.D. Chicago: Ares, 1980.

FINLEY, M. I. Diógenes, o Cínico. In: FINLEY, M. Aspectos da Antiguidade. Trad. M. B. Cipolla. São Paulo: Martins Fontes, 1991, p. 105-118.

FLORES-JÚNIOR, O. Em torno d'O cínico: nota sobre as relações de Luciano com o cinismo. Kléos, Rio de Janeiro, vol. 2/3, p. 122-133, 1998/1999.

FLORES-JÚNIOR, O. Alguns sintomas da recepção do cinismo antigo. In: LOPES, A. O. D.; LAGE, C. F; FLORES-JÚNOR, O. (Org.). Scripta Classica: história, literatura e filosofia na Antiguidade Clássica. Belo Horizonte: FALE/ UFMG, 1999a, p. 149-158.

FLORES-JÚNIOR, O. Nota sobre o sentido de typhos na tradição cínica. In: MENDES, E. A. M.; OLIVERIA, P. M.; BENN-IBLER, V. Revisitações: edição comemorativa dos 30 anos da Faculdade de Letras/ UFMG. BeloHorizonte: UFMG/ FALE, 1999b, p. 421-429.

FLORES-JÚNIOR, O. «Khortos gasteri» ou le bonheur est dans le pré: éthique et politique cyniques selon un poème de Cratès de Thèbes. Dialogue: revue canadienne de philosophie, Québec/Toronto, vol. 45, p. 647-677, 2006. 
FLORES-JÚNIOR, O. Tersites esquecido (nota sobre a parrésia segundo Michel Foucault). Kléos, Rio de Janeiro, vol. 13/14, p. 93-109, 2009/2010.

FLORES-JÚNIOR, O. Cinismo e retórica: o caso Tersites. In: ASSUNÇÃO, T.R.; FLORES-JÚNIOR, O.; MARTINHO, M. (Org.). Ensaios de retórica antiga . Belo Horizonte: Tessitura, 2010, p.227-250.

FOUCAULT, M. Le courage de la vérité: le gouvernement de soi et des autres II. Paris: Gallimard/ Seuil, 2009.

FUENTES GONZÁLEZ, P. P. Lucien de Samosate. In: GOULET, R. (Org.). Dictionnaire des philosophes antiques. Vol. IV. Paris: Éditions du C.N.R.S., 2005, p. 131-160. FUENTES GONZÁLEZ, P. P. Le Démonax de Lucien entre réalité et fiction. Prometheus, Firenze, vol. 35, p. 139-158, 2009.

FUENTES GONZÁLEZ, P. P. En defensa del encuentro entre dos Perros, Antístenes y Diógenes: historia de una tensa amistad. Cuadernos de Filología Clásica, Estudios griegos e indoeuropeos, Madrid, vol. 23, p. 225-267, 2013.

GIANNANTONI, G. (Org.). Socratis et socraticorum reliquiae. Collegit, disposuit, apparatibus notisque intruxit G. Giannantoni. Napoli: Bibliopolis, 1990 (4 vols.). GOULET-CAZÉ, M.-O. Une liste de disciples de Cratès le Cynique en Diogène Laërce 6, 95. Hermes. Berlin, 114, p. 247-252, 1986 a.

GOULET-CAZÉ, M.-O. L'ascèse cynique: un commentaire de Diogène Laërce VI 70-71. Paris: Vrin, 1986b.

GOULET-CAZÉ,M.-O. Le cynisme à l'époque impériale. In: HAASE, W. (Org.). Aufstieg und Niedergang der Römischen Welt II, 36.4. Berlin/New York, 1990, p. 2730-2833. GOULET-CAZÉ, M.-O. Les cyniques e la «falsification de la monnaie». In: PAQUET, L. (Org.). Les cyniques grecs: fragments et témoignages. Avant-propos par MarieOdile Goulet-Cazé. Paris: Le Livre de Poche, 1992a, p. 5-29.

GOULET-CAZÉ, M.-O. Le livre VI de Diogène Laërce: analyse de sa structure et réflexions méthodologiques. In: HAASE, W. (Org.). Aufstieg und Niedergang der Römischen Welt II, 36.6. Berlin/ New York: Walter de Gruyter, 1992b, p. 3880-4048.

GOULET-CAZÉ, M.-O. Le cynisme est-il une philosophie? In: DIXSAUT, M. (Org.). Contre Platon 1: Le platonisme dévoilé. Paris: Vrin, 1993, p. 273-313.

GOULET-CAZÉ, M.-O. Les kynika du stö̈cisme. Stuttgart: Franz Steiner, 2003.

HADOT, I. Du bon et du mauvais usage du terme «éclectisme» dans l'histoire de la philosophie antique. In: BRAGUE, R.; COURTINE, J.-F. (Org.). Herméneutique et ontologie: mélanges en hommage à Pierre Aubenque. Paris: P.U.F., 1990, p.147-162.

HARTOG, F. O espelho de Heródoto: ensaio sobre a representação do outro. Tradução de J. L. Brandão. Belo Horizonte: Editora da UFMG, 1999.

HELM, R. Lucian und die Philosophenschule. Neue Jahrbücher der klassischen Altertum, Leipzig, vol. 9, p. 188-213; p. 351-369, 1902.

HÉRODOTE. Histoires. Texte établi et traduit par Ph.-E. Legrand. Paris: Les Belles Lettres, 1932-1954 (9vols.). 
HOMERUS. Homeri opera. Recognoverunt brevique adnotatione criticai nstruxit David B. Munro et Thomas W. Allen. Oxford: Oxford University Press, 1920 (2 vols.).

HUSSON, S. La République de Diogène: une cité en quête de la nature. Paris: Vrin, 2011. JOLY, T. Lucien de Samosate. In: VIRÉ, G. (Org.). Grec et latin en 1980: études et documents dédiés à Edmond Liénard. Bruxelles: Université Libre de Bruxelles, 1980, p. 47-62.

JOLY, R. La réfutation des analogies dans l'Hermotime de Lucien. L'Antiquité Classique, Liège, vol. 50, p. 417-426, 1981.

LUCIANO DE SAMÓSATA. Biografias literárias. Trad. Jacyntho Lins Brandão et alii. Belo Horizonte: UFMG, 2014 (no prelo).

LUCIANO DE SAMÓSATA. Como se deve escrever a história. Trad. e ensaio de Jacyntho Lins Brandão. Belo Horizonte: Tessitura, 2009.

LUCIEN DE SAMOSATE. CEuvres. Texte établi et traduit par J. Bompaire. Paris: Les Belles Lettres, 1993-2008 (vols. I-IV).

LUCIEN DE SAMOSATE. Hermotime ou comment choisir sa philosophie? Présenté et traduit par Jean-Paul Dumont. Paris: P.U.F., 1993.

LUCIANO DE SAMÓSATA. Diálogos dos mortos. Trad. e notas de Maria Celeste Consolin Dezotti. São Paulo: Hucitec, 1996.

LUCIANO DE SAMÓSATA. Hermotimo ou As escolas filosóficas. Prefácio, trad. e notas de Custódio Magueijo. Lisboa: Inquérito, 1986.

LUCIEN DE SAMOSATE. Philosophes à l'encan. Introduction, texte et traduction par Thérèse Beaupère. Paris: Les Belles Lettres, 1967 (2 vols.).

LUCIAN OF SAMOSATE. Lucian in eight volumes. With an English translation by A. M. Harmon; M.D. Macleod et alii. Cambridge, Mass.: Harvard University Press, 1913-1967.

MACHADO DE ASSIS, J. M. Memórias Póstumas de Brás Cubas. In: MACHADO DE ASSIS, J. M. Obras completas: vol. 5 (Memórias Póstumas de Brás Cubas). Rio de Janeiro: Jackson Editores, 1961a.

MACHADO DE ASSIS, J. M. Teoria do medalhão. In: MACHADO DE ASSIS, J. M. Obras completas: vol. 12 (Papéis avulsos). Rio de Janeiro: Jackson Editores, 1961b, p. 97-115. MOLES, J. L. The Cynics and politics. In: LAKS, A.; SCHOFIELD, M. (Org.). Justice and Generosity. Cambridge: Cambridge University Press, 1995, p. 120-158.

MOLES, J. L. Le cosmopolitisme cynique. In: GOULET-CAZÉ, M.-O.; GOULET, R. (Org.). Le cynisme ancien et ses prolongements. Paris: P.U.F., 1993, p. 259-280.

NESSELRATH, H.-G. Lucien et le cynisme. L'Antiquité Classique, Liège, vol. 67, p. 121-135, 1998.

PAQUET, L. Les cyniques grecs: fragments et témoignages. Ottawa: Les Presses Universitaires d'Ottawa, 1988.

PLATON. Le Banquet. Texte établi et traduit par P. Vicaire, avec le concours de J. Laborderie. In: PLATON. Euvres complètes, vol. IV $-2^{\mathrm{e}}$ partie. Paris: Les Belles Lettres, 1989. 
REGO, E. de S. O calundú e a panaceia: Machado de Assis, a sátira menipeia e a tradição luciânica. Rio de Janeiro: Forense, 1989.

RELIHAN, J. C. Ancient Menippean Satire. Baltimore/ London: The Johns Hopkins University Press, 1993.

RICH, A. N. M. The Cynic conception of autarkeia. Mnemosyne, Amsterdam, vol. 9, p. 23-29, 1956.

ROMANO, R. Silêncio e ruído. A sátira em Denis Diderot. Campinas: Editora da Unicamp, 1996.

ROMERI, L. Philosophes entre mots et mets: Plutarque, Lucien et Athénée autour de la table de Platon. Grenoble: Jérôme Millon, 2002.

ROUANET, S. P. Riso e melancolia: a forma shandiana em Sterne, Diderot, Xavier de Maistre, Almeida Garret e Machado de Assis. São Paulo: Companhia das Letras, 2007.

SCHOFIELD, M. The stoic idea of the city. Chicago: The University of Chicago Press, 1999.

SCHWARTZ, J. Biographie de Lucien de Samosate. Bruxelles: Latomus, 1965.

SPINA, L. L'oratore scriteriato: per una storia letteraria e politica di Tersite. Napoli: Loffredo Editore, 2001.

TORRES FILHO, R. R. Ensaios de filosofia ilustrada. São Paulo: Brasiliense, 1987. 